Savunma Bilimleri Dergisi

The Journal of Defense Sciences

Mayıs / May 2021, Say1/Issue 39.

ISSN (Bas1l1) : 1303-6831 ISSN (Online): 2148-1776

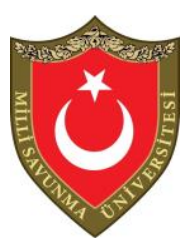

\title{
Savunma Tedarik Proje Yönetiminde Entegre Proje Ekiplerinin Kullanımına Yönelik Bir Model Önerisi*
}

\author{
Mustafa Kemal TOPCU**
}

$\ddot{O} z$

Tedarik projelerinin belirlenen performans kriterlerine zamaninda ve hedeflenen maliyet sinırları içerisinde ulaşabilmesi için etkin ve başarılı bir proje yönetimi anlayışına ihtiyaç duyulmaktadır. Başta savunma, havacılık ve uzay sanayi gibi uzun vadeli karmaşı ksistem tedarikinde entegre proje ekiplerinin kullanılması söz konusu riskleri azaltmanın bir yöntemi olabilir. Ancak kullanıcı ihtiyaçları, yüklenici pozisyonu, ekonomi ve teknoloji gibi belirsizliklerin yoğun olduğu, mali, teknik ve takvim açısından risk yönetiminin ön planda tutulduğu savunma sektöründe entegre proje ekiplerinin kullanılmasina yönelik çalışmalar yetersiz, hatta yok denecek kadar azdır. Alanyazındaki bu yetersizliğe vurgu yapmak ve gelişen savunma sektöründe entegre proje ekiplerinin kullanılmasına katkıda bulunmak maksadiyla hazırlanan bu çalışmanın amacı, Türkiye'de entegre proje ekiplerin kullanımına yönelik bir model önerisi sunmak olarak belirlenmistir. Özgün teknolojik savunma sistemine sahip olmak isteyen Türkiye açısından ekosistemdeki tüm aktörlerin teknoloji ve iş yapış tarzının sinerji yaratacak şekilde bir araya getirilmesi çalışmanın önemini artırmaktadır. Bu doğrultuda bu çalışmada, Türkiye'de savunma tedarik projelerinde kullanılabilecek örnek bir entegre proje ekip yapısl, ekibin oluşum aşamaları, çalışma talimatı ve kontrol listesi önerilmektedir.

Anahtar Kelimeler: Entegre Proje Ekibi, EPE, Proje Yönetimi, Savunma Tedariki.

\footnotetext{
* Bu çalışma Yöneylem Araştırması ve Endüstri Mühendisliği 31. Ulusal Kongresinde "Tedarik Programı Yönetiminde Entegre Proje Ekiplerinin Kullanımı" başlığı ile sunulan bildirinin geliştirilmiş halidir.

** Dr., ST Strateji ve Teknoloji Geliştirme Ltd.Şti., mktopcu@ ststrateji.com, ORCID: 00000002-3298-1283

Geliş Tarihi/Received : 24.02.2020

Kabul Tarihi/Accepted : 27.11.2020

Derleme Makalesi/Review Article DOI: $10.17134 /$ khosbd.913768
} 


\title{
A Model Proposal for Employing Integrated Project Teams in Project Management in Defense Acquisition
}

\begin{abstract}
It is of great necessity of project management concept to complete acquisition projects within identified performance criteria in compliance with time and cost targets. Employing integrated project teams may be a tool to mitigate mentioned risks in acquisition of long-term complex systems in particularly defense, aviation, and space sector. However, there is a scant literature on employment of integrated project teams in defense sector whereby uncertainties due to user requirements, supplier position, economy and technology are confronted and risk management regarding finance, technic, and schedule are attached great significance. This study, which is prepared to highlight the need and contribute to the use of integrated project teams in developing defense sector, aims to propose a model regarding employing integrated project teams in Turkey. Gathering know-how and technology of the actors in ecosystem to create synergy on behalf of Turkey, aiming to have indigenous defense technology, promotes the significance of the study. To this end, this study proposes an integrated project team organizational chart, team formation phases, operational procedures, and a checklist to be employed in defense acquisition projects in Turkey.
\end{abstract}

Keywords: Integrated Project Team, IPT, Project Management, Defense Acquisition.

\section{Giriş}

Kendine has özellikleri ile diğer sektörlerden ayrılan savunma sanayi projelerinde risklerin ortaya çıkmasındaki etken konular arasında yetersiz finansal kaynak ile projenin yürütülmesi, geliştirilmiş ve kullanılmakta olan iş akışına uymayarak tekerleğin yeniden keşfetmeye çalışılması, en güncelin ve en fazlanın istenmesi, iletişimin güçlendirilmemesi ve insan kaynakları uygulamalarından yeterince yararlanılmaması yer almaktadır (Turk, 2006b: 25-27). Özellikle insan kaynakları uygulamaları proje yönetiminin en kritik yönünü oluşturmaktadır (Gadeken, 2005: 11; Pinheiro, 2010: 5). Nitekim proje riskleri değerlendirildiğinde nitelikli iş gücü ilk sırada gelmektedir (Korkmazyürek, 2004: 215). 
Savunma Tedarik Proje Yönetiminde Entegre Proje Ekiplerinin Kullanımına Yönelik Bir Model Önerisi

Riskleri kontrol altına almak için uygulanacak yöntemlerden birisi de, erken aşamadan itibaren tedarik zinciri içerisinde ileriye ve geriye doğru yer alan aktörlerle iş birliği stratejisidir. Tedarik makamının sanayi ile iş birliği yapması; yetenek geliştirmek, yatırım tekrarlarından kaçınmak ve kaynak israfını önlemek için kullanılan bir araçtır. Özellikle özgün tasarımların gerçekleştirilmesi ve kaynakların etkin kullanılması için kullanıcı makam, tedarik makamı ve sanayi kesiminin iş birliği yapması önemlidir (Korkmazyürek, 2004). Bu doğrultuda 1990'ların ortasından itibaren ABD'de simülasyon tabanlı tedarik ve İngiltere'de akıllı tedarik sistemlerinde entegre proje ekipleri (EPE) kullanılmıştır. Benzer şekilde evrimsel tedarikin aşamalı ve spiral geliştirme modelleri, müşterek yetenekler entegrasyonu ve geliştirme konsepti ile sistem yaklaşımı kapsamında EPE kullanımına yer verilmeye başlanılmıştır. Böylelikle tedariki yapılacak savunma yeteneğinde tüm tarafların yetkinliğinden faydalanılmaktadır. Özellikle karmaşık, belirsiz, uzun süreli ve çok taraflı projelerde EPE'nin kullanımı giderek daha önemli bir hale gelmektedir.

Bununla birlikte teknoloji yönetimi kapsamında EPE'ler tamamen anlaşılamamıştır (Bochenek ve Ragusa, 2004: 10). Ayrıca, savunma sektörü gibi teknolojideki hızlı değişim, tehdit algısı, kullanıcı ihtiyaçları, yüklenici pozisyonu, ekonomik vb. nedenlerden dolayı belirsizliğin yoğun olduğu ve mali, teknik ve takvim açısından risk yönetiminin ön planda tutulduğu bir sektörde EPE'lerin program yönetiminde kullanılmasına yönelik çalı̧̧malar yetersizdir, hatta yok denecek kadar azdır. Alanyazındaki bu yetersizliğe vurgu yapmak ve gelişen savunma sektöründe EPE’lerin kullanılmasına katkıda bulunmak maksadıyla hazırlanan bu çalışmanın amacı, Türkiye'de EPE'lerin kullanımına yönelik bir model önerisi sunmak olarak belirlenmiştir. Özellikle ulusal alanyazında neredeyse hiç değinilmemiş bir konu olması çalışmanın önemini artırmaktadır. Özgün teknolojik savunma sistemine sahip olmak isteyen Türkiye açısından, ekosistemdeki tüm aktörlerin teknoloji ve bilgisinin sinerji yaratacak şekilde bir araya getirilmesi ise çalışmanın önemini bir kat daha artırmaktadır. Bu doğrultuda öncelikle proje yönetimi, savunma tedarik stratejileri ve EPE kavramsal olarak ele alınmaktadır. Akabinde savunma tedarik programlarında EPE'lerin kullanılma durumları incelendikten sonra tedarik makamlarının uygulamalarına yönelik bazı önerilere yer verilerek çalışma sonlandırılmaktadır. 


\section{Proje Yönetimi}

Modern işletme hayatının her alanında gelişen teknoloji, yeni stratejilerin kullanılmasını zorunlu hale getirmiştir (Pinheiro, 2010). Teknoloji ile birlikte karmaşıklığın ve belirsizliğin de arttığı görülmektedir. Buchanan (1991) yeni teknolojinin donanım, yazılım, ağlar, haberleşme bağlantıları, sistemler, süreçler ve yönetim uygulamalarından oluştuğunu ifade etmektedir. Bunlarla birlikte, yeni pazar yaratma çabaları ile birlikte karşılaşılan küreselleşme sonucunda sürdürülebilirlik konuları, yeni iş dünyasının vazgeçilmez bir unsuru haline gelmiştir. $\mathrm{Bu}$ yoğun rekabet ortamı tüm sektörleri değişime ve proje odaklı çalışmaya zorlamıştır. Küreselleşme, kaynak kitlığ ve yoğun rekabet ortamı gibi parametreler de işletmeleri proje yönetimine yöneltmektedir (Pinheiro, 2010). Nitekim araştırma geliştirme faaliyetleri ile birlikte yüksek teknoloji yatırımlarının artarak devam etmesi proje yönetiminin giderek daha ön plana çıkacağına işaret etmektedir (Söderlund ve Bredin, 2006: 249).

Proje yönetimi, genel olarak belirli bir ihtiyacı karşılamak üzere, belirli bütçe ile belirli bir zaman diliminde benzer faaliyetlerin bir araya getirilmesidir (PMI, 2013). Esasen proje yönetimi; bilgilerin, süreçlerin, becerilerin, araçların ve tekniklerin, projenin gereksinimlerini yerine getirmek amaciyla proje aktivitelerine uygulanmasıdır. Özetle, proje yönetimini; faaliyetleri sistematik ve disiplinli bir yol izleyerek organizasyon, liderlik ve raporlama ile yapma sanatı olarak ifade etmek mümkündür. Faaliyetler, Şekil 1'de gösterildiği gibi fonksiyonel uzmanlıklar şeklinde belirli bir sıra dâhilinde yapılmaktadır.

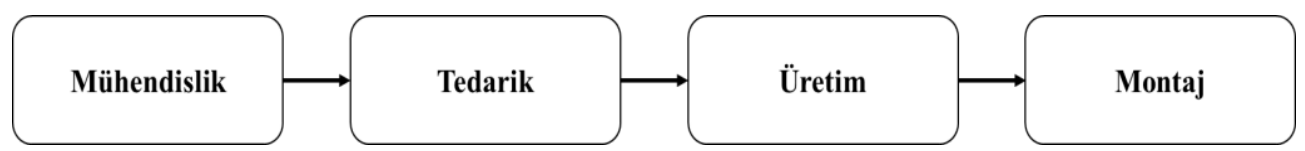

Şekil 1. Geleneksel Proje Yönetimi Metodolojisi (Fleming ve Koppelman, 1996)

\section{Proje Yönetim Ekipleri}

Proje ekibi, başından sonuna kadar projenin yürütülmesi için ilgili konularda uzman kişilerin belirli bir amaç doğrultusunda bir araya gelmesiyle oluşan bir gruptur (İstanbul Sanayi Odas1, 2009: 39). Proje ekibinde aranan unsurlar; nitelikler, beceriler, deneyim, kişilik özellikleri, örgütsel değerler ve kültürle uyumlu iş etiğidir (Pinheiro, 2010: 5). Hatta kişilik ve tutumlar, bazen tecrübe ve beceriden daha da ön 
Savunma Tedarik Proje Yönetiminde Entegre Proje Ekiplerinin Kullanımına Yönelik Bir Model Önerisi

plana çıkabilmektedir (Turk, 2006a: 23). Bilgi, beceri ve yetenek ile birbirlerini tamamlayan kişilerden oluşan proje ekipleri, birbirlerine karşı sorumluluğa da sahiptir.

Projenin başarılı çıktılar ortaya koyabilmesi ancak uyumlu bireylerin bir araya gelmesiyle mümkündür (İstanbul Sanayi Odası, 2009). Nitekim Rahman ve Kumaraswamy (2008: 48) de en iyi çıktıya ulaşmak için entegre ekip çalışmasını ve kapsamlı bir iş birliği oluşturulmasını tavsiye etmektedir. Böylece tüm paydaşların çıkarları, ihtiyaçları, beklentileri, kısıtları ve riskleri hesaba katılabilmektedir. Kısacası proje, mali ve beşerî kaynakların etkin kullanımı ile başarıya ulaşabilir (Pinheiro, 2010).

Geleneksel birbirini takip eden fonksiyonel yapılar yerine proje ekiplerinin kullanılması, temel olarak bekleme zamanlarını ortadan kaldırarak işlem süresinin kısaltılması faydasını sağlamaktadır. Örneğin; eş zamanlı mühendislik; ürün tasarımından etkilenen herkesin tasarım bilgisine olabildiğince erken ulaşması ve gelecekte yaşanabilecek problemlerin önüne geçmesi için son tasarıma dâhil olmasını sağlayan bir metodolojidir (Bochenek ve Ragusa, 2004: 5). Bilgi akışını hızlandırarak ilk aşamalardan itibaren tüm paydaşların erişimine olanak sağlayan eş zamanlı mühendislik belirsizliğin azalmasını sağlamaktadır (Koufteros vd., 2001). Şekil 2'de yer alan eş zamanlı mühendislik, tüm birimlerin katkısını proje ömür devrinin her aşamasında beklemektedir.

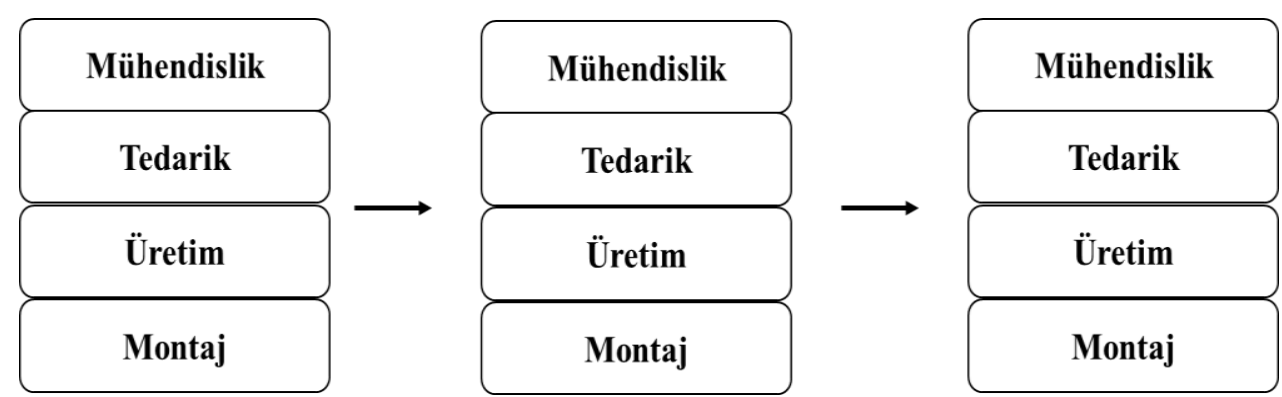

Şekil 2. Eş Zamanlı Mühendislik (Fleming ve Koppelman, 1996)

Multi-fonksiyonel ekipler, faaliyetleri fonksiyonlar arasında bütünleştirerek, tasarım ve üretim süreçlerini uyumlaştırarak ve proje planlama safhasına vurgu yaparak projelerde daha yüksek tasarım kalitesine, envantere daha kısa sürede alınmasına, ürün ailesinin daha hızlı planlanmasına ve daha verimli fikirlerin ortaya 
çıkmasına neden olmaktadır (Hayes, Wheelwright ve Clark, 1988; Hitt, Hoskisson ve Nixon, 1993). Multi-fonksiyonel ekipler, ürünü ve üretim süreçlerini geliştirme, tasarım çıktılarını iyileştirme faydalarını sağlamaktadır. Ayrıca multi-fonksiyonel ekipler, pazar ve müşteri gereksinimlerini karşılayan ürün yaratılması ile ilgili bilgi akışını hızlandırmakta ve kolaylaştırmaktadır (Zakarian ve Kusiak, 1999: 85). Bunlarla birlikte, multi-fonksiyonel ekiplerin nihai kullanıcıların katılımına erken aşamalarda izin vermesi, birimler arası iletişimi artırması, teknik bilgiye erişimi kolaylaştırması, kaynakların etkin kullanımı ile amaç uyumunu sağlaması gibi organizasyonel faydalarından da bahsetmek mümkündür (Ford ve McLoughlin, 1992).

Amerikan Ordusu dâhil çoğu organizasyonun, sistem ve ürün ömür devrini kısaltmak ve maliyeti azaltmak için; tasarım, üretim, konfigürasyon yönetimi, test ve lojistik gibi tüm disiplinlerin bir araya gelmesine olanak veren bütünleşik ürün geliştirme ekipleri tasarım, üretim ve destek planlarının gereksinimlerini netleştirerek zaman kaybını önleyebilmektedir (Menker, 1990: 27). Bu doğrultuda bütünleşik ürün geliştirme ekipleri güçlendirilmiş, işbirlikçi, multi-disipliner, yönetilebilir bir yapı sunmaktadır. Bütünleşik ürün geliştirme ekiplerinde nitelikli kişilerin yer alması kadar etkili organizasyonel yapının oluşturulması ile proseslerin düzenlenmesi de önemlidir (Menker, 1990: 27). Bütünleşik ürün geliştirme ekibi geleneksel olarak Şekil 3 'te yer alan birimlerin temsilcilerinden oluşturulabilir.

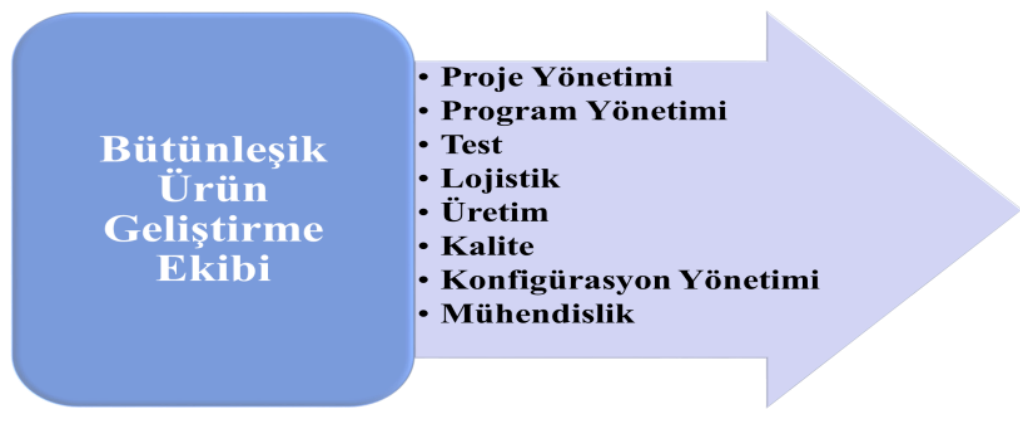

Şekil 3. Bütünleşik Ürün Geliştirme Ekibi (Menkel, 1990: 29)

Ürün spesifikasyonuna göre yer alacak üyenin uzmanlık alanı farklılık gösterebilir. Örneğin; bir radar projesinde bakım uzmanı, kalite uzmanı, yazılım 
Savunma Tedarik Proje Yönetiminde Entegre Proje Ekiplerinin Kullanımına Yönelik Bir Model Önerisi

mühendisi ve elektronik harp uzmanı gibi yetkin kişiler görev yaparken, daha karmaşık bir proje olarak değerlendirilebilecek hava aracı projesinde finans uzmanı, test mühendisi, veri uzmanı ve sistem mühendisi gibi ilave kadrolara rastlanabilir. Özellikle başlangıçta oluşturulan ekibin, proses boyunca korunması, ekip içi rol ve sorumlulukların netleştirilmesi ile ekibin ekip içi ve dışı iletişim kurallarının belirlenmesi önemlidir (Menker, 1990: 30).

\section{Entegre Proje Ekipleri}

Yukarıda izah edilen multi-fonksiyonel ekiplerde, eş zamanlı mühendislik ve bütünleşik ürün geliştirme ekipleri gibi yapılarla birlikte EPE'lerin kullanıldığına da rastlanmaktadır (Fleming ve Koppelman, 1996). Bu kavramların ortak yanı bir amaç doğrultusunda farklı birimlerden bireylerin katılımıyla proje ekibinin oluşturulmasıdır. Çalışmanın bu kısmında EPE'ler detaylı bir şekilde ele alınmaktadır.

\section{a. Kavramsal olarak Entegre Proje Ekipleri}

EPE'ler benzer yapılardaki çabaları bir aşama daha ileri taşımaktadır. Pek çok organizasyon özellikle ürün geliştirme ömür devri maliyetini ve süresini azaltmak için çok fonksiyonlu EPE'lerin aracılığıyla eş zamanlı iş birliği modelini kullanmaktadır (Bochenek ve Ragusa, 2004). Entegrasyon; profesyonel, örgütsel, operasyonel ve millî kültürlerden oluşan iş birliği gayretlerinin etkin bir şekilde birleştirilmesi, optimal proje sonuçları ve yüksek seviye performans seviyeleri açısından uyumluluğun geliştirilmesi olarak tanımlanmaktadır (Rahman ve Kumaraswamy, 2008: 62). Ayrıca, ekipte yer alanlar kendi uzmanlık alanı içerisinde sistem ile ilgili konuları, fikirleri, parametreleri ve performansları değerlendirmektedir (Bochenek ve Ragusa, 2004: 7). Bu açıdan, EPE, tasarım ve icra faaliyetlerini, hatta idari faaliyetlerini de tüm paydaşların katılımıyla yürütmektedir (OGC, 2007: 4). EPE'lerin oluşturulmasında projenin kapsamı ve iş kırılım yapısı etkendir. EPE oluşturulurken proje ömrünün hangi fazında hangi paydaşların ne derecede katılması gerektiği belirlenmelidir. Tablo 1'de bir bilgi teknolojileri projesi için yapılan paydaş katılımı belirleme çalışması örnek olarak verilmiştir. 
Tablo 1. Bilgi Teknolojileri Projesi İçin Örnek Paydaş Katılımı (MITRE, 2008: 6)

\begin{tabular}{|c|c|c|c|c|c|c|c|}
\hline & \multicolumn{7}{|c|}{ Proje Fazları } \\
\hline & (1) & (2) & (3) & $(4)$ & (5) & (6) & (7) \\
\hline Sponsor & $\begin{array}{l}\text { Karar } \\
\text { Verme }\end{array}$ & $\begin{array}{l}\text { Karar } \\
\text { Verme }\end{array}$ & $\begin{array}{l}\text { Karar } \\
\text { Verme }\end{array}$ & Destek & $\begin{array}{l}\text { Karar } \\
\text { Verme }\end{array}$ & $\begin{array}{l}\text { Karar } \\
\text { Verme }\end{array}$ & $\begin{array}{l}\text { Karar } \\
\text { Verme }\end{array}$ \\
\hline Son Kullanıcı & $\begin{array}{l}\text { Karar } \\
\text { Verme }\end{array}$ & $\begin{array}{l}\text { Karar } \\
\text { Verme }\end{array}$ & $\begin{array}{l}\text { Karar } \\
\text { Verme }\end{array}$ & Destek & $\begin{array}{l}\text { Karar } \\
\text { Verme }\end{array}$ & $\begin{array}{l}\text { Karar } \\
\text { Verme }\end{array}$ & $\begin{array}{l}\text { Karar } \\
\text { Verme }\end{array}$ \\
\hline İcra Komitesi & İzleme & İzleme & İzleme & İzleme & İzleme & İzleme & İzleme \\
\hline Tedarikçiler & & Destek & & & & & \\
\hline Yükleniciler & & Destek & Destek & Destek & Destek & Destek & \\
\hline $\begin{array}{l}\text { Yazilım } \\
\text { Geliştiriciler }\end{array}$ & & Destek & $\begin{array}{l}\text { Karar } \\
\text { Verme }\end{array}$ & $\begin{array}{l}\text { Karar } \\
\text { Verme }\end{array}$ & $\begin{array}{l}\text { Karar } \\
\text { Verme }\end{array}$ & Destek & Destek \\
\hline $\begin{array}{l}\text { Konfigürasyon } \\
\text { Birimi }\end{array}$ & & Destek & Destek & Destek & Destek & Destek & Destek \\
\hline Altyapı Birimi & Destek & Destek & $\begin{array}{l}\text { Karar } \\
\text { Verme }\end{array}$ & Destek & $\begin{array}{l}\text { Karar } \\
\text { Verme }\end{array}$ & $\begin{array}{l}\text { Karar } \\
\text { Verme }\end{array}$ & Destek \\
\hline $\begin{array}{l}\text { Güvenlik } \\
\text { Birimi }\end{array}$ & Destek & Destek & $\begin{array}{l}\text { Karar } \\
\text { Verme }\end{array}$ & Destek & & $\begin{array}{l}\text { Karar } \\
\text { Verme }\end{array}$ & \\
\hline Test Birimi & & Destek & & & Destek & $\begin{array}{l}\text { Karar } \\
\text { Verme }\end{array}$ & \\
\hline $\begin{array}{l}\text { Operasyon } \\
\text { Birimi }\end{array}$ & Destek & Destek & $\begin{array}{l}\text { Karar } \\
\text { Verme }\end{array}$ & Destek & $\begin{array}{l}\text { Karar } \\
\text { Verme }\end{array}$ & $\begin{array}{l}\text { Karar } \\
\text { Verme }\end{array}$ & $\begin{array}{l}\text { Karar } \\
\text { Verme }\end{array}$ \\
\hline
\end{tabular}

Not: Proje Fazları (1) Konsept Tasarım (2) Gereksinimleri Geliştirme (3) Tasarım (4) Geliştirme Uygulama Test Kullanıma Alma

Tablo 1'de savunma tedarik projelerinde de uygulanan proje fazları baz alınarak paydaşların rol ve sorumlulukları netleştirilmiştir. EPE'leri diğer proje ekiplerinden ayıran temel özellik, projenin tasarım aşamasından itibaren farklı disiplinlerden (örneğin; teknoloji, endüstriyel, finansal, yasal, lojistik gibi) uzmanlara yer vermesidir (Darnis vd., 2007: 7). Örneğin son kullanıcı geliştirme aşamasında destek sorumluluğu üstlenirken, diğer aşamalarda karar verme sürecinde yer almaktadır. Genellikle geliştirme aşamasında son kullanıcıdan beklenen, gereksinim dokümanına uygun bir şekilde ürün/hizmet ile ilgili geri bildirimde bulunmasıdır. Görüldüğü üzere, proje yönetim planının oluşturulması aşamasında, paydaş analizi yapılması ve paydaşların iş kırılım yapısına uygun olarak aktivitelerle eşleştirilmesi planlamayı kolaylaştırmaktadır. 
Savunma Tedarik Proje Yönetiminde Entegre Proje Ekiplerinin Kullanımına Yönelik Bir Model Önerisi

\section{b. Entegre Proje Ekiplerinin Yararları}

EPE'ler projelere ilişkin girdileri, analizleri ve karar verme süreçlerini etkin bir şekilde kullanabilmek için gerekli olan bilgi, beceri, yetenek, araç ve bakış açılarını bir araya getiren yapılardır. EPE'ler proje ömür devri boyunca birlikte çalıştığ1 için değişikliklere uyum sürecini hızlandırmakta ve daha proaktif bir yaklaşım sergileyebilmektedir (Fleming ve Koppelman, 1996). EPE'lerin normal çalışma gruplarına kıyasla öne çıkan özellikleri Tablo 2'de gösterilmektedir.

Tablo 2. Grup Çalışması ve EPE Karşılaştırma Tablosu (MITRE, 2008)

\begin{tabular}{|l|l|l|}
\hline \multicolumn{1}{|c|}{ Kriter } & \multicolumn{1}{c|}{ Çalışma Grubu } & \multicolumn{1}{c|}{ EPE } \\
\hline Karar Verme & Merkeziyetçi & Ekip Kararı \\
\hline Liderlik & Otoriter & Katılımcı \\
\hline Hesap Verilebilirlik & Birey & Birey ve Ekip \\
\hline Amacın Esnekliği & Esnek Değil & Ekibin Etkisine Açık \\
\hline Çıktılar & Bireysel & Ekip Çalışması \\
\hline Etkileşim & Tartışmasız Kabullenme & $\begin{array}{l}\text { Eleştirel Yaklaşım ve } \\
\text { Katılımcı Problem Çözme }\end{array}$ \\
\hline Katılımcılık & Birey Katılımı Önemsiz & Sürekli Katılım \\
\hline Performans & $\begin{array}{l}\text { Görevin Tamlığı ve } \\
\text { Bireysel Çaba }\end{array}$ & Ekip Performansı \\
\hline Görevlendirme & Lider & Ekip \\
\hline
\end{tabular}

EPE’lerin sahada kullanımında iyi uygulama örneği olarak yeni ürün geliştirme ekipleri gösterilebilir. Yeni ürün geliştirme sürecinde EPE'lerin kullanılması sonucunda ürün geliştirme süresinin kısaldığı, geliştirme maliyetinin azaldığı ve ilk defada sıfir hata ile istenilen kalitede ürün elde edildiği gözlenmiştir (Fleming ve Koppelman, 1996: 164).

EPE'lerdeki iş birliğinin yarattı̆̆ faydayı dört başlık altında özetlemek mümkündür (Sanderson, 2009).

- Üretim, tedarik ve teslimat süreçlerinin uyumlaştırılmasına bağlı olarak maliyetlerde azalma,

- Tasarım aşamasından itibaren yapılan bilgi paylaşımının doğurduğu etkili öğrenme ile daha hızlı ve uygun inovasyonu sağlama, 
- Daha hızlı tespit edilen ve çözüme kavuşturulan kalite sorunları sonucunda israfin azalması, bekleme sürelerinde kısalma ve

- Müşteri gereksinimlerindeki değişikliklere daha hızlı cevap verebilme.

\section{c. Entegre Proje Ekiplerine Yöneltilen Eleştiriler ve Gelişime Açık}

\section{Yönler}

EPE'lerin kullanılmaya başlanması bir kurumsal kültür değişimidir (Cook, 1998). Zira EPE, farklı çalışma ortamı ve kurumsal kültürden bireylerin bir araya gelmesi demektir (Moore ve Antill, 2001). Nitekim Sanderson (2009) tarafindan vurgulandığı gibi asıl konu müşteri olarak devletin tedarikçilerle iş birliği için bir dil geliştirmesidir. Örneğin; kamu sektörü harcamalarını mevzuata uygun yapmak durumunda iken özel sektör daha etkin harcama yapmayı düşünmektedir. Kamunun ve özel sektörün performans yönetim sistemleri birbirinden farklıdır. Öte yandan kamu sektörü bağlamında özel sektörle iş birliği yapılması şeffaflık, sorumluluk, mali saydamlık ve hesap verilebilirlik açısından uygun görülmeyebilir (Erridge ve Nondi, 1994). Kamu, daha uygun maliyetle yaratacağ çalışırken, özel sektör ekonomik faydayı önceliklendirmektedir (Moore ve Antill, 2001). Bu nedenlerle, EPE'lerde amaç uyumu ön plana çıkmaktadır. Ekip çalışmasının iş birliğine dönüşebilmesi için tarafların açık olabilmesi, beklentilerini net bir şekilde ifade edebilmesi, hedeflerini uyumlaştırabilmesi ve çıkar çatışmalarını tüm paydaşlarının menfaatine olacak şekilde çözümleyebilmesi önemlidir. Taraflar beklentilerini, hedeflerini açıkça ortaya koymadıkça, nihai üründe karşı1ıklı fayda sağlamadıkça ekip çalışmasından bahsetmek mümkün değildir (OGC, 2007: 6). Ancak tüzel kişiler, ticari gizlilik kaygısıyla veri paylaşmaktan kaçınabilmektedir. Ayrıca Erridge ve Greer (2000), kamu ve özel sektör arasında yapılacak iş birliğinin haksız rekabet doğuracağını belirtmektedir.

Pane Haden, Humphreys, Cooke ve Penland (2012) tarafindan üst düzey yöneticilerle yapılan mülakatlar sonucunda, EPE'lerde üyelerin bağlanma sorunu yaşadığı ortaya çıkmıştır. Bu problemin çözümü açısından EPE liderinin seçim ve eğitiminin önemli olduğu vurgulanmıştır. Ayrıca liderin finansal harcama yetkisi ve üyelerin performansını değerlendirmesinin bu anlamda vazgeçilmez iki unsur olduğu karşımıza çıkmaktadır. 
Savunma Tedarik Proje Yönetiminde Entegre Proje Ekiplerinin Kullanımına Yönelik Bir Model Önerisi

EPE'lere getirilen eleştirilerin içerisinde örgütsel faktörlerden kaynaklanan işgücü devir hızının yüksek olmasına bağlı olarak, iş sürekliliğinin ve kurumsal hafizanın sağlanamaması yer almaktadır (McKinsey \& Co, 1998: 11). EPE'lerin temel felsefesi; multi-fonksiyonel bir ekip tarafından yönetim olduğu halde projenin yürütücü otoritesi değiştiğinde EPE'lerin de görevine son verilmektedir (Moore ve Antill, 2001).

Uygulamaların gözden geçirilmesi sonucunda EPE'lerin başarısızlık sebepleri aşağıdaki gibi sıralanabilir (Pinheiro, 2010: 2).

- Çok başl11ık,

- Örgütsel boş vermişlik,

- Yukarıdan aşağıya planlama,

- Aşağıdan yukarıya uygulamaların yapılmaması,

- Proje ekibince yeterince benimsenmeme,

- Program yöneticisinin yetkinliğinin olmaması,

- Proje planlarının belirsizliği,

- Muğlak rol ve sorumluluklar,

- Ekip tükenmişliği,

- Etkisiz değişim yönetimi,

- Zayıf örgütsel kültür.

Sonuç olarak, EPE’lerde ekip çalışması kültürü, ortak sorumluluk bilinci, kalite odaklılık, gelişime açıklık, yetkilendirme, planlı çalışma, sonuç odaklılık, iletişim, maliyet bilinci ve sürdürülebilirlik önemlidir. $\mathrm{Bu}$ nedenle EPE'lerin yetkinlik çerçevesi oluşturulurken risk oluşturacak bu alanlara özel önem verilmelidir.

\section{Savunma Tedarik Projelerinde Entegre Proje Ekipleri}

EPE'ler savunma tedarik projeleri bağlamında İngiltere'deki akıllı tedarik sistemleri ile ABD'de simülasyon tabanlı ve evrimsel tedarik sistemlerinde etkin bir şekilde kullanılmaktadır (Müslüm, Topcu ve Mala, 2010: 112). Nitekim kullanıcı ihtiyaçlarının proje ömür devri boyunca hesaba katılması ve her aşamada tüm 
paydaşların devrede olması gerektiğinden yeni savunma yeteneklerinin kazanılması ve mevcut yeteneklerin geliştirilmesi bir zorunluluk haline gelmiştir. Öyle ki, kritik silah sistemlerinin üretilmesinde ömür devrinin yaklaşı \%70'ini oluşturan operasyonların yönetilmesi için multi-disipliner bir yapıya ihtiyaç duyulmuştur (İngiltere Savunma Bakanlığı, 2005: 105). Ullah, Tang ve Yin (2015) tarafindan yapılan araştırmada, proje maliyetlerinin \%70-80'lik kısmının ilk aşamalarda kararlaştırıldığını, ancak projelerde \%56 oranında değişiklik meydana geldiğini göstermektedir. Bu nedenle, son kullanıcıların ihtiyaçlarının tanımlanması için ilk aşamada paydaşların tamamını bir araya getirmek en uygun yöntemdir. $\mathrm{Bu}$ çerçevede, çalışmanın bu kısmında öncelikle savunma tedarik stratejileri gözden geçirilecek, daha sonra savunma sistemleri açısından EPE'lerin kullanımı incelenecektir.

\section{Savunma Tedarik Stratejileri}

Savunmada tedarik, kıt kaynaklarla uygun süre içerisinde en son teknolojiyle donatılmış silah sistemlerinin envantere alınmasının sağlanmasıdır (Topcu, Mala ve Müslüm, 2015: 96). Bir tarafta teknoloji kazanımı söz konusu iken, diğer taraftan mümkün olan kısa sürede silahlı kuvvetlerin teçhiz edilmesi söz konusudur. $\mathrm{Bu}$ nedenle gereksinimlere odaklı geleneksel tedarik stratejileri yerini yetenek tabanlı tedarik stratejilerine bırakmaktadır. Bu doğrultuda simülasyon tabanlı tedarik stratejisi, akıllı tedarik stratejisi, evrimsel tedarik stratejisi, müşterek yetenekler entegrasyon ve geliştirme sistemi ile sistem mühendisliği yaklaşımı tercih edilen güncel tedarik stratejileri ve yaklaşımlarıdır. $\mathrm{Bu}$ stratejilerin ortak noktası, tedarikçileri erken aşamalarda sürece dâhil etmesidir. Böylelikle tedarikçiler sistem ve ürün tasarımı ile tasarım iyileştirmelerine katkı sağlayabilmektedir (Cohee, Barrows ve Handfield, 2019). Bahsi geçen strateji ve yaklaşımlar bu bölümde ele alınmıştır.

Simülasyon tabanlı tedarik 1990'ların sonuna doğru yaygınlaşan bir tedarik stratejisi olmuştur. ABD Savunma Bakanlığı Tedarik Komitesi (1997) simülasyon tabanlı tedariki bakanlık ile sanayinin proje ömrü devrince simülasyon teknolojisinin müşterek kullanılması olarak tanımlamaktadır. İngiltere Savunma Bakanlığı (2005) da simülasyon tabanlı tedariki, akıllı tedarik hedeflerinin daha hızlı, daha az maliyetli ve daha uygun şekilde tedarik edilmesi için modelleme, simülasyon ve sanal ortamın proje ömür devrince kullanılması olarak tarif etmektedir. Simülasyon tabanlı 
Savunma Tedarik Proje Yönetiminde Entegre Proje Ekiplerinin Kullanımına Yönelik Bir Model Önerisi

tedarikin iyi uygulamaları arasında Crusader kundağı motorlu obüs, Comanche ve Apache taarruz helikopterleri, JSF taarruz uçağı, Virginia-sınıf denizaltı, LPD-17 amfibi gemi ve DD-21 gelecek nesil savaş gemisi projeleri gösterilebilir (Zittel, 2001).

Gross, Tucker ve Cameron (2007), simülasyon tabanlı tedarik stratejisinin amaçlarını, proje süresini, maliyetini ve risklerini azaltmak, toplam sahiplik maliyetini azaltırken projenin kalitesini artırmak ve proje ömür devrince entegre ürün ve süreç geliştirmeyi mümkün kılmak olarak sıralamaktadır. Simülasyon tabanlı tedarik stratejisinde özen gösterilmesi gereken alanlar; modelleme ve simülasyon araçlarının birlikte çalışabilirliği, veri güvenliği, fiziksel testler, donanımsal ve yazılımsal kısıtlamalar, kullanımına yönelik teşvikler, yetkin işgücü, veri sahipliği ve fonlama şeklinde sıralanabilir.

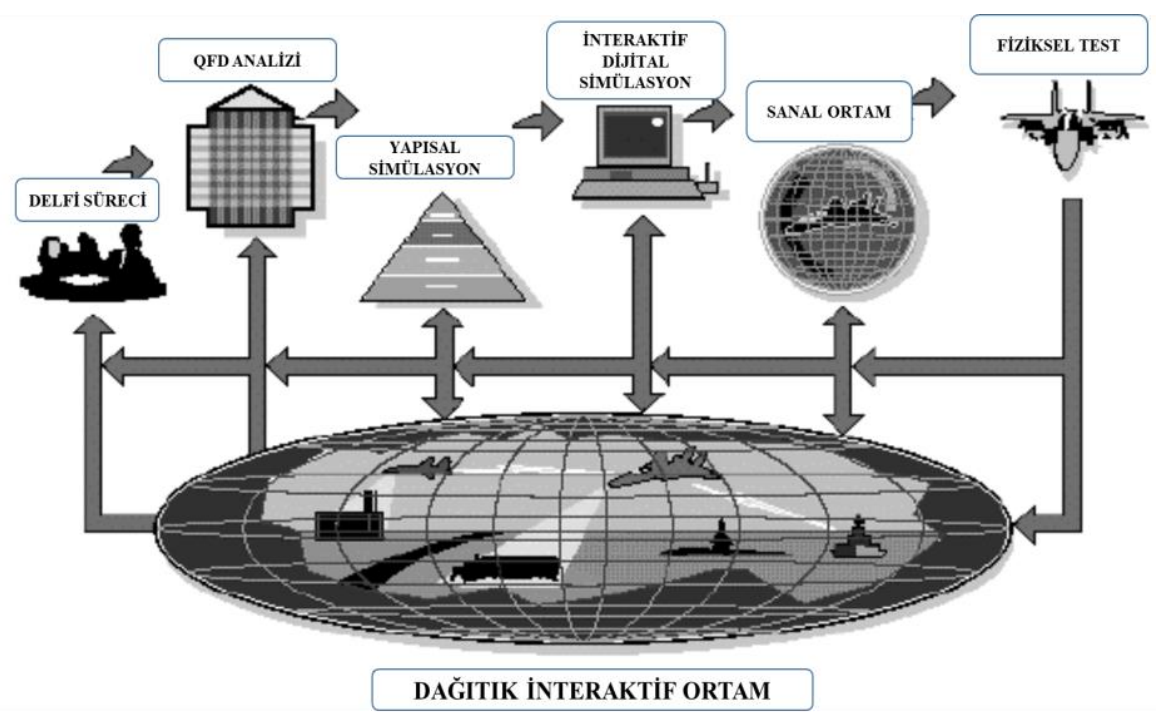

Şekil 4. Simülasyon Tabanlı Tedarik Süreci (Hollier ve Becket, 2002)

Şekil 4'te resmedilen simülasyon tabanlı tedarik sistemini teknolojiden ibaret düşünmek yanıltıcı olabilir. İşgücü, politikalar ve süreçler birbirini bütünleyerek tedarik sisteminin işleyişini desteklemektedir (Zittel, 2001).

ABD özellikle teknoloji geliştirmeyi içeren ana savunma sistemlerinin çoğunda aşamalı modelleri ile spiral modelleri bulunan evrimsel tedarik stratejisini kullanmaktadır (Mortlock, 2020: 266). ABD Savunma Bakanlığı operasyonel 
gereksinimlerin karşılanması için evrimsel tedarik stratejisi ile aşamalı modeli tercih etmektedir (Office of the Under Secretary of Defense for Acquisition, Technology \& Logistics, 2007). Fox (2011), evrimsel tedarikin tercih nedeni olarak gelişmiş teknolojinin son kullanıcının kullanımına erken aşamada sunulması gerektiğini göstermektedir. Diğer yandan evrimsel tedarik stratejisini ABD'nin ileri araştırma ajans1 olan Defense Advanced Research Projects Agency (DARPA) karmaşık tedarik bürokrasisini aşmanın bir yolu olarak kullanmıştır (Ellman, 2009). Evrimsel tedarik stratejisinde temel hedef gereksinimlerle mevcut yetenekleri kısitl kaynaklarla karşılayabilmek ve teslimatını hızlı bir şekilde yapabilmektir (Fox, 2011). Evrimsel tedarik stratejisi ileri teknoloji yeteneklerin bir an evvel envantere alınmasını sağlarken, kullandığı aşamalı ya da spiral geliştirme modelleri ile zaman içerisinde daha gelişmiş teknolojinin kazanımına olanak sağlamaktadır (Aldridge, 2002). Kullanılan modellerden ABD'nin de öncelikle tercih ettiği aşamalı model Şekil 5’te gösterildiği gibidir.

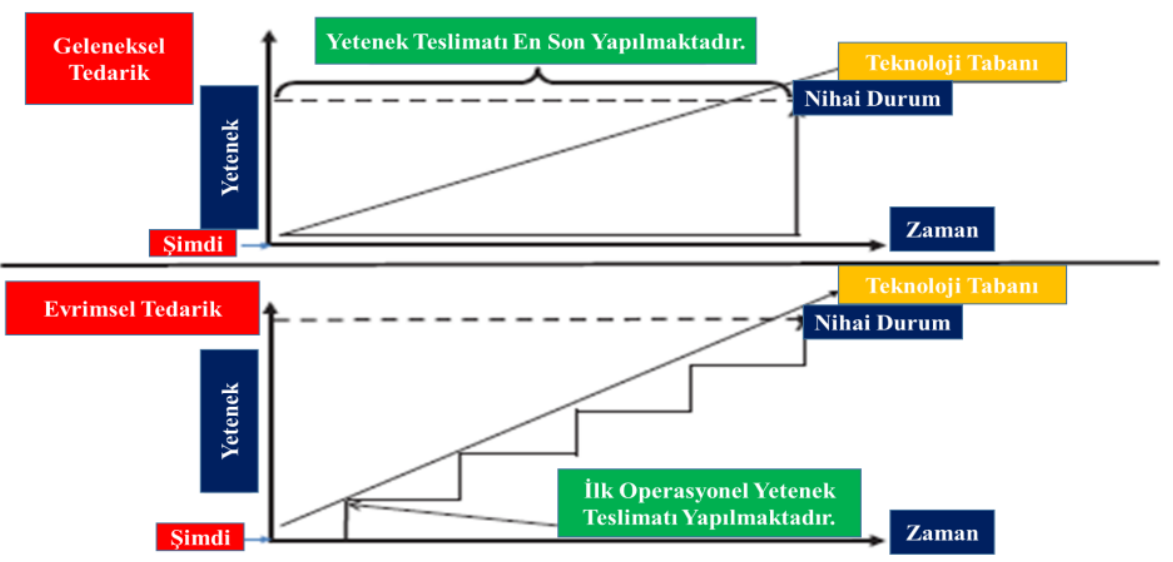

Şekil 5. Evrimsel Tedarik Stratejisi Aşamalı Model (Mortlock, 2020: 266)

Şekil 5'te görüldüğü gibi geleneksel tedarik stratejisinde yetenek teslimatı hedeflenen nihai yetenek kazanımında yapılmaktadır. Diğer bir ifade ile ihtiyaç sahibi tarafından belirlenen gereksinimler karşılanıncaya kadar yetenek teslimatı yapılmamaktadır. Aşamalı modelde ise operasyonel yeteneği ilk aşamada teslim etmek esastır. Teknoloji kazanımı ilerledikçe gereksinimlerin karşılanma derecesi artmakta ve konfigürasyon geliştirilmektedir. 
Savunma Tedarik Proje Yönetiminde Entegre Proje Ekiplerinin Kullanımına Yönelik Bir Model Önerisi

Çok paydaşın eşzamanlı mühendislik uygulamalarını gerektiren yazılımyoğun savunma sistemlerinde kullanılan spiral model risk tabanlı bir süreç yaklaşımıdır (Boehm ve Hansen, 2001). Spiral modelde gereksinimler deneysel uygulamalarla ve risk yönetimiyle sürekli geri bildirimlerle iyileştirilirken, bu yöntem ile her aşamada kullanıcıya en uygun yeteneğin kazandırılması söz konusudur (Aldridge, 2002). Spiral modelde elde edilmek istenen yetenek tarif edilebilirken, nihai duruma ilişkin gereksinimler net bir şekilde ortaya konamamaktadır (ABD Savunma Bakanlığı, 2007). Aşamalı modelden ayrılan yönleri ise çevrimsel bir yapıda risk odaklılığı ve kontrol noktası olarak kullanılan mihenk taşlarında paydaşların katılımını sağlamasıdır (Boehm ve Hansen, 2001).

Müşterek yetenekler entegrasyon ve geliştirme sistemi, müşterek karargah tarafindan müşterek harekat kabiliyeti ve ihtiyaçları belirlemek ve gidermek üzere kullanılan sistematik bir metodolojidir. ABD tarafindan 2003 yılından itibaren karar destek sistemi olarak kullanılmaya başlanan bu süreç Şekil 6'da gösterildiği gibi hedeflenen müşterek kabiliyetin konsepte dayalı belirlenmesine bağlıdır.

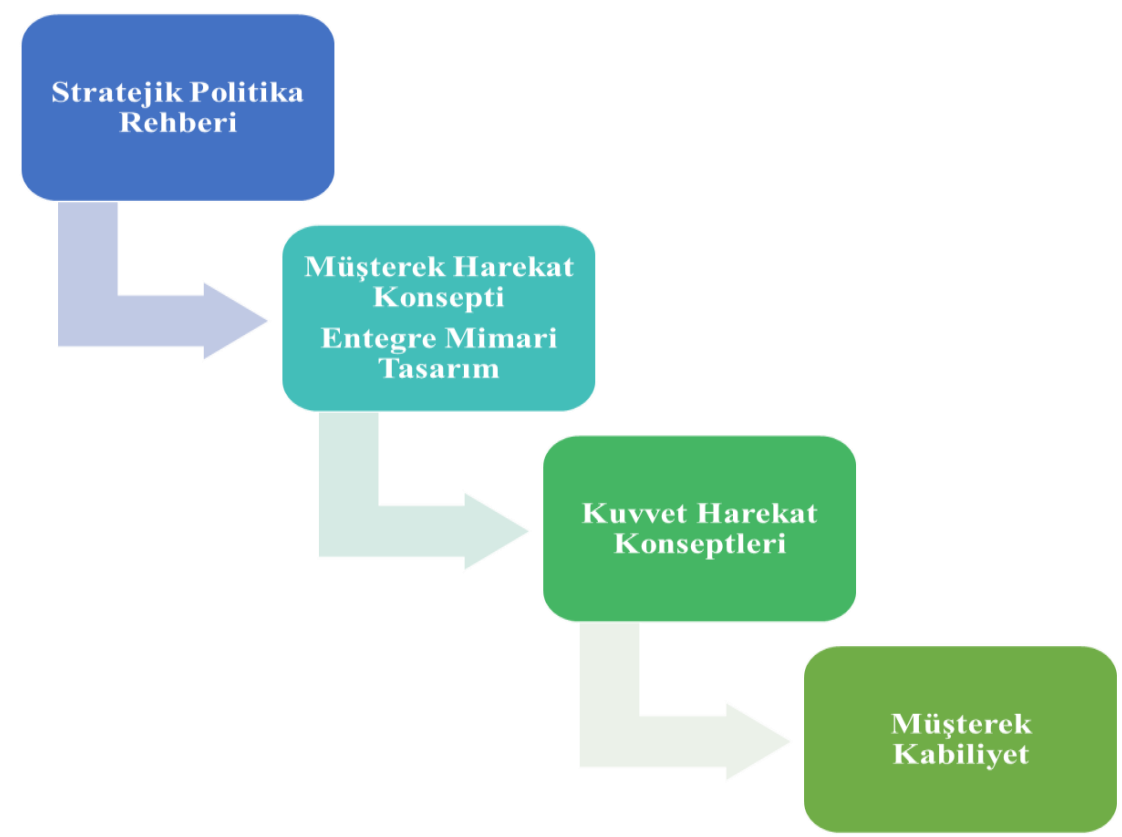

Şekil 6. Yetenek Tabanlı Tedarik (Liu, Liu, Xu ve Zhang, 2012) 
Stratejik politika rehberinin hazırlanmasının ardından belirlenen müşterek harekat konsepti, kuvvet harekat konseptlerine 1şık tutmaktadır. Müşterek yetenekler entegrasyon ve geliştirme sistemi ile tehdit odaklı tedarik stratejileri yerini yetenek tabanlı stratejilere bırakmıştır. Sistemin odak noktası gereksinimlerden ziyade yeteneklerdir (Liu vd., 2012). Böylelikle sistem zafiyetleri ile birlikte mükerrerlikler ve ihtiyaç fazlası sistemler de tespit edilebilmektedir. Özellikle yetenek tabanlı değerlendirmeyi yapabilmek için öncelikle arzu edilen nihai yeteneklerin tespit edilmesi önemlidir. Bu aşamada multi-disipliner bir ekip tarafından yapılacak çalışma bu sistemin bel kemiğini oluşturmaktadır (Guo, Li ve Yang, 2008).

Sistem mühendisliği yaklaşımı, güncel tedarik stratejilerinin tamamında uygulanan, farklı sistem geliştirme, entegrasyon ve sürdürülebilirlik yeteneklerini birleştiren, süreç ve modelleri temsil eden bütünleyici bir yaklaşımdır (Gove ve Uzdzinski, 2013:688). Sistem mühendisliği yaklaşımı Şekil 7'de gösterilmektedir.

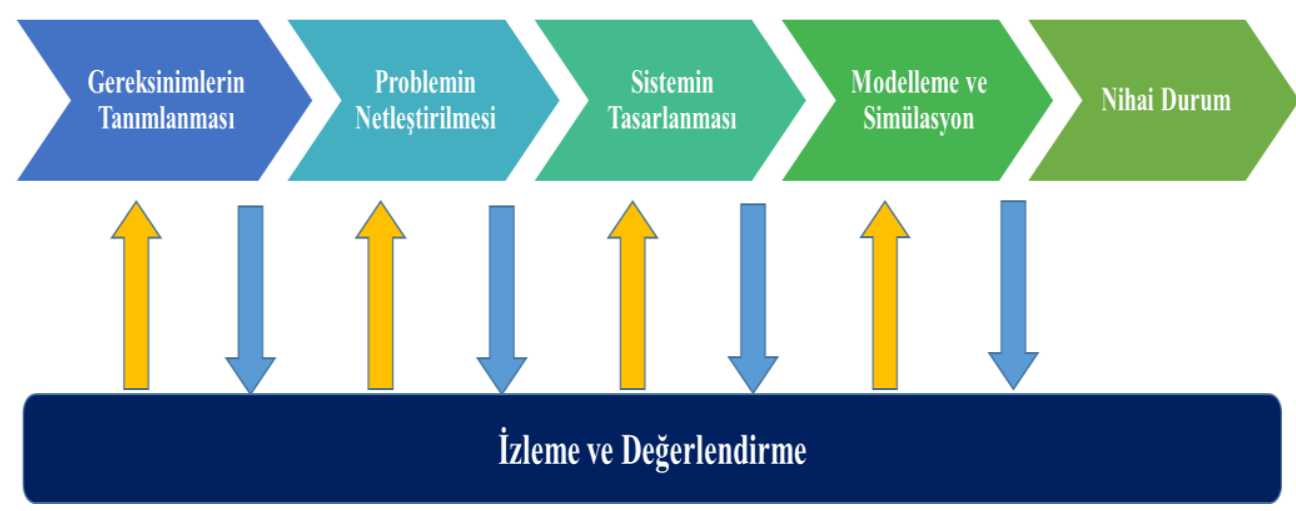

Şekil 7. Sistem Yaklaşımı (Coble vd., 2014: 13)

NASA (2017)'ya göre sistem mühendisliğinin amac1, sistemlerin mümkün olduğu kadar maliyet etkin bir şekilde tasarlanması, yapılması ve işletilmesidir. Sistem mühendisliği yaklaşımı tedarik ömür devrince erken aşamalarda paydaşların müdahalesini mümkün kıldığı için avantaj sağlamaktadır (Cook, Nowakowski ve Unewisse., 2013). Bu süreçte performans, maliyet, süre ve riskler her aşamada dikkate alınabilmektedir (NASA, 2017). Savunma silahları uzun vadede ortaya çıkan sistemler olduğu için ideal bir uygulama alanı olmuştur. Bahill ve Gissing (1998) tarafından "State, Investigate, Model, Integrate, Launch, Assess, Re-evaluate" süreci 
Savunma Tedarik Proje Yönetiminde Entegre Proje Ekiplerinin Kullanımına Yönelik Bir Model Önerisi

olarak tarif edilen ve SIMILAR olarak kısaltılan sistem yaklaşımında problemin tanımlanması, alternatiflerin araştırılması, sistemin modellenmesi, sistem entegrasyonun yapılmas1, sistemin hizmete alınmas1, performansinın değerlendirilmesi ve iyileştirmelerin yapılması söz konusudur. Buradan hareketle savunma projelerinin tedarik sistemine uyarlanan sistem yaklaşımı; gereksinimlerin tanımlanması ve problemin yeniden ifadesi ile başlayarak kapsamın ortaya konulmasıdır (Coble vd., 2014: 14). Sistem tasarımı aşamasında varsayımlar belirlenmekte ve saha gereksinimleri netleştirilmekte, böylelikle sistem modellenebilmektedir. Sistemin simülasyonuyla tasarım mimarisinde düzenlemeler yapılabilmektedir. Böylelikle nihai durum için alternatifler ortaya konarak, teknoloji kazanımı kolaylaştırılmaktadır.

Bir diğer tedarik yaklaşımı da İngiltere'de 1997 yılında uygulamaya alınan ve liberal yapısıyla dikkat çeken akıllı tedarik sürecidir (Calcara, 2017: 7). Daha uygun silah sistemlerini daha az maliyetle daha hızı bir şekilde envantere almayı hedefleyen akı1lı tedarik konsepti daha uzun süreli uluslararası savunma projelerinde iş birliğini ön plana çıkarmıştır (Mawdsley, 2015). Aynı dönemde ABD'de tedarikte, gereksinimlerde ve eğitimde simülasyon ve modelleme şeklinde (SMARTSimulation and Modelline in Acquisition, Requirements and Training) benzer yaklaşım uygulanmıştır (Bochenek ve Ragusa, 2003). İngiltere'de 1980'lerde başlayan libarelleşme sonucunda savunma sanayi firmaları tamamen özelleştirilmiş ve daha sonra konsolidasyon gerçekleşmiştir. Örneğin havacılık ve uzay alanında BAE Systems firması ortaya çıkmıştır. Bu süreçte proje yönetiminde proje ömür devrince ihtiyaç duyulan farklı bilgi ve becerilerin kullanılması EPE'ler marifetiyle sağlanmıştır (Kirkpatrick, 2003). Aşamalı geliştirmeyi içeren akıllı tedarik sürecinde yetenek daha uygun maliyetle ve daha düşük risk seviyesinde geliştirilen silahın envantere alınmasını ve teknolojilerdeki gelişmeleri de hesaba katarak silahın geliştirilmesini öngörmektedir. Akıllı tedarik süreci; konsept, değerlendirme, gösterim, üretim, envantere alma ve elden çıkarma olmak üzere altı aşamadan oluşmaktadır (Calcara, 2017).

\section{2. İyi Uygulama Örnekleri}

Avrupa Birliği (AB) tarafından hazırlanan savunma projelerine yönelik alınan dersler raporunda en başarılı projelerin EPE'ler tarafından yönetildiği belirtilmiştir (Darnis vd., 2007: 7). Örneğin; İngiltere'de yüksek düzeyde sistem 
mühendisliği becerisine sahip bir sistem entegratörü önderliğindeki EPE tarafindan yürütülen ve ulusal/uluslararası firmalar için üretilen Geleceğin Hızlı Etki Sistemleri (Future Rapid Effecting Systems-FRES) platformları projesi tasarım, üretim ve yenileme ile ilgili karmaşıklıkların, zorlukların ve maliyetlerin çok küçük ekipler tarafından da yönetilebileceğini göstermiştir (İngiltere Savunma Bakanlığı, 2005: 17).

Benzer şekilde, ABD Savunma Bakanlığı tarafından tedarik maliyetini azaltmak ve tedarik süresini kısaltmak ve geleneksel ihale sürecinde yaşanan sorunları aşmak için kullanılan simülasyon tabanlı tedarik stratejisi; EPE vasıtasıyla daha kaliteli sistemleri daha ekonomik ve daha kısa sürede tedarik etmek maksadıyla tasarlanmıştır (Bochenek ve Ragusa, 2004). Simülasyon tabanlı tedarik sistemlerinin hedefi; ömür devrince EPE'lerin kullanılmasını sağlamaktır. Bu şekilde çok fonksiyonlu ekiplerin oluşturulması ve projelerin aşamalarında iş birliği yaratması ile kullanıcıların ilk safhalardan itibaren projelere dâhil edilmesi teşvik edilmektedir (Bochenek ve Ragusa, 2004: 3). Bu şekilde tedarik program sürelerinin \%50 azaltılması hedeflenmiştir.

EPE'lerce savunma tedarik projelerine değer katmak için tasarım geliştirme, tasarım değişikliklerini azaltma, alınan dersleri uygulama, çatışmaları çözümleme, kalite, zaman ve ömür devri maliyeti optimize edilmektedir (OGC, 2007: 7). ABD Hava Kuvvetlerinde uygulanan "High-Performance Team" örneği süreyi optimize etmekle kalmamış, gereksinim dokümanının hazırlanması ile hedef maliyetinin, piyasa koşullarının ve spesifikasyonların da kolaylıkla belirlenebileceğini göstermiştir (Moore ve Antill, 2001).

Diğer taraftan, AB'nin Çok Maksatlı Firkateyn (Multi Mission Frigates FREMM) projesi, EPE'lerin uluslararası konsorsiyum bağlamında kullanımına bir örnek teşkil edebilir. $\mathrm{Bu}$ tarz uluslararası projelerde konsorsiyum oluşturulur oluşturulmaz EPE'lerin görev yapması istenebilir. Bu nedenle ülkeler arasındaki müzakere sözleşme metnine dönüşmeye başladığı andan itibaren EPE'lerin oluşturulması proje yönetimi açısından daha uygundur (Darnis vd., 2007: 33).

\section{Entregre Projelerinin Kullanımına Yönelik Tespit ve Değerlendirmeler}

Savunma tedarik projelerinin genelinde bir ekip çalışması yapıldığı görülmektedir. Ne var ki bu ekipler ya EPE'lerin özelliklerini taşımamakta ya da 
Savunma Tedarik Proje Yönetiminde Entegre Proje Ekiplerinin Kullanımına Yönelik Bir Model Önerisi

sadece bir ekip olarak isimlendirilmektedir (ABD Denetim Ofisi, 2001). Sadece ekip oluşturmakla yetinilmemesi gerektiğini belirten İngiltere Savunma Bakanlığı (2005), ekiplerin proje ömrü boyunca çalışabilmesi için ihtiyaç duyacağı bilgi, beceri ve yeteneklerin ortaya çıkmasını sağlayacak ortamın yaratılmasının önemine vurgu yapmıştır. Ancak mevcut ihale sistemleri statik olduğu için EPE oluşturulması ile ilgili regülasyonlara uyum bağlamında somut bir yaklaşımın söz konusu olduğu da ifade edilememektedir (Rahman ve Kumaraswamy, 2008: 48).

İhale kurallarına uymakla bağlantılı olarak EPE'lerin kompozisyonunda bazı sorunların yaşanması gayet doğal karşılanabilir. Zira yüklenici olup olmayacağı yönünde çekinceleri bulunan istekliler, tasarım aşamasında yeterli katkıyı vermekle birlikte ücretlendirme kısmında ticari gizlilik kaygısıyla hareket edebilir ve detay bilgi vermeyebilir (İngiltere Sayıştay, 2005). Bu durumda EPE, iş birliğini geliştirmekten ziyade kısıtlayan bir mekanizmaya dönüşmektedir (Sanderson, 2009). Burada altı çizilecek konu, kamu ile sanayi arasındaki iş birliğinin güvenli, açık ve şeffaf bir iletişime dayanması gerekliliğidir (İngiltere Savunma Bakanlı̆̆ı, 2005).

EPE'lere benzer yapıların teşkili ile kullanıcı/ihtiyaç makamının faaliyetlere daha etkin katılabilmesi için hukuki altyapı oluşturulmalıdır (Müslüm vd., 2010: 112). Özellikle mali mevzuat EPE’lere harcama yetkisi tanıyacak şekilde düzenlenebilir (Müslüm vd., 2010: 111). EPE lideri ihtiyaçların bütçelenebilir, başarılabilir ve ölçülebilir olmasını sağlamak için ekibini oluşturmaktadır (Turk, 2006a: 25). EPE'lerde yer alacak üyelerin seçimi kritik olduğu kadar üyelerin güncel bilgi ve becerilerinin eğitimlerle desteklenmesi de önemlidir (Dwivedi \& Kumbakonam, 2002; Winn, 2006). Üst yönetim; iş birliği yaklaşımına ve ekip çalışması etiğine sahip olmalı ve iyi yönetim kuralları çerçevesinde örnek davranış sergilemelidir (OGC, 2007:6). Liderin beşerî ilişkileri yönetme yetkinliğinin daha fazla olması arzu edilmektedir (Carman, 2009). Ancak Pane Haden ve arkadaşları (2012) tarafından EPE liderleri ile yapılan görüşmeler sonucunda, proje bütçesi ile iş gücünün etkili kullanımı konusunda yeterli yetkilendirme yapılmadı̆̆ belirtilmiştir. Halbuki EPE’lere karar almada serbestlik tanınması önemlidir. Ancak üst yönetimin desteği alınmadıkça, EPE'lere yeterli bütçe sağlanması konusu problem olmaya devam edecektir. Üst yönetimin kaynak sağlaması, kararların alınması ve diğer paydaşların desteklenmesi açısından önemlidir (Turk, 2006a: 23). 
Bunlarla birlikte organizasyonlarda EPE'lerin kullanımına uygun bir yapı bulunmaması temel sorunlardan biridir (MITRE, 2008). Sadece teknik konularda değil finansal, hukuki, sözleşme, lojistik ve ihtiyaç duyulan alanlarda da uzmanların katılımı sağlanmalı, son kullanıcılar başlangıçtan itibaren projeye dâhil edilmelidir (Turk, 2006a: 23). Özellikle ihtiyaçların belirlenmesi ve test aşamasına katılım kesinlikle sağlanmalıdır. Hatta plansız ve bağımsız test merkezleri de sürece dâhil edilmelidir.

Organizasyon yapısı ile birlikte EPE'lerin çalışma usul ve esasları ile ilgili belirsizlikler de mevcuttur. Özellikle konsept geliştirme ve ihtiyaç belirleme aşamalarında bilgilere kolay erişim sağlayacak iş akışına ihtiyaç duyulmaktadır. EPE çalışma talimatında; ihtiyaç, kapsam, amaç, beklenen sonuçlar, çıktılar, performans, yetki ve sorumluluk, dış prosedürler ve etkileşimi, üyelerin nitelikleri ve karar verme süreci olmalıdır (MITRE, 2008).

Rol belirsizliği ile ekip üyeleri arasındaki çatışmayı önlemek için; EPE liderinin ve ekibinin sorumlulukları ile görevleri açıkça tanımlanmalıdır (Pinheiro, 2010: 5). Yönetici, takvim ve arzu edilen sonuçları açıkladıktan sonra işin yapılış tarzını EPE üyelerine bırakmalıdır. EPE'lerde iş yapış tarzını alanında uzman olan ve farklı yetenek ve tecrübeleri bulunan proje ekibine bırakmak ve sadece gerekli kontrolleri yapmak sonuçların tutarlılığını sağlamak için yeterli olacaktır (Turk, 2006a: 23). Bu açıdan EPE'lere mevcut durum, yürütülen faaliyetler ve gelecek planları hakkında geri besleme yapmak, olan biten hakkında onları bilgilendirmek süreci kolaylaştırabilir (Turk, 2006b: 27). Kısacası, EPE’lerde karşılıklı güven ve açıklık esastır.

Yukarıda yapılan tespit ve değerlendirmeler 1şı̆̆ında EPE'lerin daha etkili çalışabilmesi için düzeltilmesi gereken konuların aşağıdaki gibi sıralanması mümkündür (Hughes Aircraft Company, 1994).

- Örgütlerin fonksiyonel yapılanmasından gerektiği kadar destek alınmamas1,

- $\quad$ Ekip çalışması için planlama becerisinin yetersizliği,

- Çatışma yönetiminde beceri yetersizliği,

- Ekibin yeterince bir araya gelmemesi, 
Savunma Tedarik Proje Yönetiminde Entegre Proje Ekiplerinin Kullanımına Yönelik Bir Model Önerisi

- Eğitimlerin yetersizliği,

- Alınan derslerin ya da bilginin paylaşılmaması,

- Mevcut verilerin ekip çalışmasına uygun olmaması,

- İletişim yetersizliği, özellikle zorluklar yaşandığında ekibin dışarı ile iletişimini kesmesi,

- Özellik arz eden uzmanlıklardan yoksun olunması,

- Performans göstergelerinin uygun şekilde belirlenmemesi,

- Ödüllendirme sisteminin bireysel olmas1,

- Finansal raporlama sisteminin fonskiyonel yapıya uygun olmaması,

- Yetersiz dokümantasyon.

\section{Türkiye için Model Önerisi}

Türkiye açısından savunma tedarik projelerinde EPE'lere yer verilmesinin faydalı olacağı düşünülmektedir. Ancak akla gelen bazı soruların da cevaplanması önemlidir. Gelişen sanayiyle birlikte paydaşların artması sonucunda EPE'lerin oluşumunda denge ne kadar gözetilebilir? Özellikle kamu alımlarını düzenleyen regülasyonlar göz önünde bulundurulduğunda, haksız rekabet koşullarının yaratılmasının önüne nasıl geçilebilir? EPE’lerde görevlendirilecek asker ve sivil çalışanların rotasyon durumları ne şekilde yönetilebilir? Teknoloji kazanımı hedefinde kritik olan know-how oluşumu nasıl sağlanabilir ve nasıl muhafaza edilebilir? O hâlde savunma tedarik projelerinin yönetsel süreçlerinin iyi tasarlanmış ve uygulanıyor olması önemlidir (Turk, 2006b: 25). Süreçlerin oluşturulmasında tamamlanan projelerden elde edilen tecrübeler esas alınmakla birlikte risk odaklı bir yaklaşımla karşılaşılabilecek muhtemel durumlar da düşünülerek esnek tasarımlar yapılmalıdır. Buradan hareketle muhtemel riskler içerisinde nitelikli işgücü, kamuüniversite-sanayi iş birliği, regülasyona uyum konuları ön plana çıkmaktadır. Bu çalışmada, Türkiye açısından EPE’lerin kullanımına yönelik değerlendirilmede, öncelikle risklere yönelik öneriler sıralanmış, akabinde süreç içerisinde kullanılabilecek bir EPE yapısı, çalışma usul ve esasları ile kontrol listesi önerilmiştir. 
Tedarik proje yönetiminin amacı, maliyetleri minimize etmek yerine değerin artırılması şeklinde değişmiştir. $\mathrm{Bu}$ nedenle tedarik zincirlerinde uzun dönemli ilişkiler kurulması doğal karşılanmaktadır (OGC, 2007: 7). Tedarik zinciri içerisinde yer alan alt yükleniciler ürünün \%60-70'ini karşıladığı hâlde EPE yapısında yer alamamaktadır (Dowdall, 2004). Bu nedenle ana yüklenicilik sisteminde EPE'lerin kullanımının irdelenmesi bir zorunluluk hâline gelmiştir. Türkiye'de millî ana yüklenicilik sistemi benimsendiği için önceliği ana yüklenicilerin alması kaçınılmaz olmakla birlikte alt yüklenicilere de uygun şekilde yer verilmesi önem arz etmektedir. Nitekim karmaşı savunma sistemlerinin tedarikinde, tedarik makamlarının proje yönetimi ve sisteme ilişkin teknik konulardaki bilgi ve tecrübe eksikliği, ana yüklenici sisteminde problem yaşanmasına neden olmaktadır (Grasso, 2010). EPE'ler sanayinin katılımı tedarik zinciri içerisinde yer alabileceği gibi proje ile doğrudan ilgili olmayarak da gerçekleşebilir. Örneğin; projede yüklenici veya alt yüklenici olarak yer almayan birisi proje lideri olarak görevlendirilebilir. $\mathrm{Bu}$ durumda kazanımların tüm paydaşlar tarafından benimsenmesi gerekmektedir.

Sanayinin teknoloji hazırlık seviyesinin artırılması için EPE'lerde yer alması faydalı olacaktır. Kullanıcıdan yükleniciye tüm paydaşların yer alacağı EPE’ler vasitasıyla operasyonel değerlendirmeler mümkün olduğu kadar erken yapılabilecek ve kullanıcı geri beslemeleri sisteme kazandırılabilecektir. Bu doğrultuda EPE'lerin teşkil edilmesi ve kullanıcı/ihtiyaç makamının faaliyetlere daha etkin katılabilmesi için hukuki altyapının oluşturulması önemlidir. Özellikle mali mevzuat EPE'lere harcama yetkisi tanıyacak şekilde düzenlenmelidir (Müslüm vd., 2010: 111-112). Ancak sanayinin katılımının güçlendirilmesi için kamu tarafından desteklenmesine ihtiyaç duyulmaktadır. Örneğin; EPE’lerde yer alan kamu, özel sektör veya sivil toplum temsilcilerinin görev yerlerinin proje ömrü boyunca değişmemesi, kamu görevlilerinin yer değiştirme gibi uygulamalarında EPE'lerdeki durumunun göz önüne alınmas1, EPE'lerin bağlı olduğu kuruluşun proje ömrü boyunca değişmemesi, EPE'lerin kendini yöneten ekipler tarzında yapılandırılması şeklinde düzenlemeler yapılabilir.

EPE'ler proje ömür devir maliyetlerinin ve tasarımın kaliteye yansımasının sorumluluğunu kolektif bir şekilde üstlenebilmelidir. Bu nedenle, EPE'lerde çalışan personel güçlendirilmelidir. Tedarik sisteminin çatısını oluşturan makamların bünyesinde teşkil edilecek EPE'lerin etkili bir proje yönetimi yapabilmesi için 
Savunma Tedarik Proje Yönetiminde Entegre Proje Ekiplerinin Kullanımına Yönelik Bir Model Önerisi

personel eğitimine önem verilmelidir (Müslüm vd., 2010: 112). Önceden proje çalışanları deneme yanılma yoluyla tecrübe edinirken, hizmet tedarikçilerinin sunduğu imkânlar sayesinde meslek içi eğitimler ve sertifika programları daha profesyonel bir yapıya bürünmüştür (Turk, 2007). Bu nedenle, EPE’lerde yer alacak kişiler örgün eğitimle edinecekleri akademik bilginin yanı sıra iş tabanlı öğrenme yaklaşımıyla alacağı hizmet içi eğitimlerle donatılmalıdır. EPE oluşturulduğunda kişiler oryantasyon eğitimine tabi tutulabilir, kültürel farklılıkların yönetilmesi ve farklı kültürlerde çalışma bu programa dâhil edilebilir. Bu açıdan yetkili tedarik makamının EPE'lere proje yönetiminin alt bileşenlerinde uzmanlık desteği vermesi faydayı artıracaktır. Çünkü kamunun bu şekilde destek sağlaması, kararların alınması ve diğer paydaşların desteği için önemlidir (Turk, 2006a: 23).

Yukarıda yer alan tartışmalar ve bilgiler doğrultusunda ana savunma sistemlerinin tedarik projesi için örnek bir EPE yapılanması Şekil 8'deki gibi olabilir. Burada önerilen EPE güçlendirilmiş bir lider önderliğinde özerklik tanınmış iş yapış tarzı ile zorlayıcı işlerin dahi üstesinden gelebilecek özelliktedir. Özellikle hızlı karar vermek için ilgili tüm birim ve uzmanlık alanlarından tecrübe barındıran bu yapıda ekip üyelerinden çok yönlü beceri de beklenmektedir.

\section{EPE Lideri}

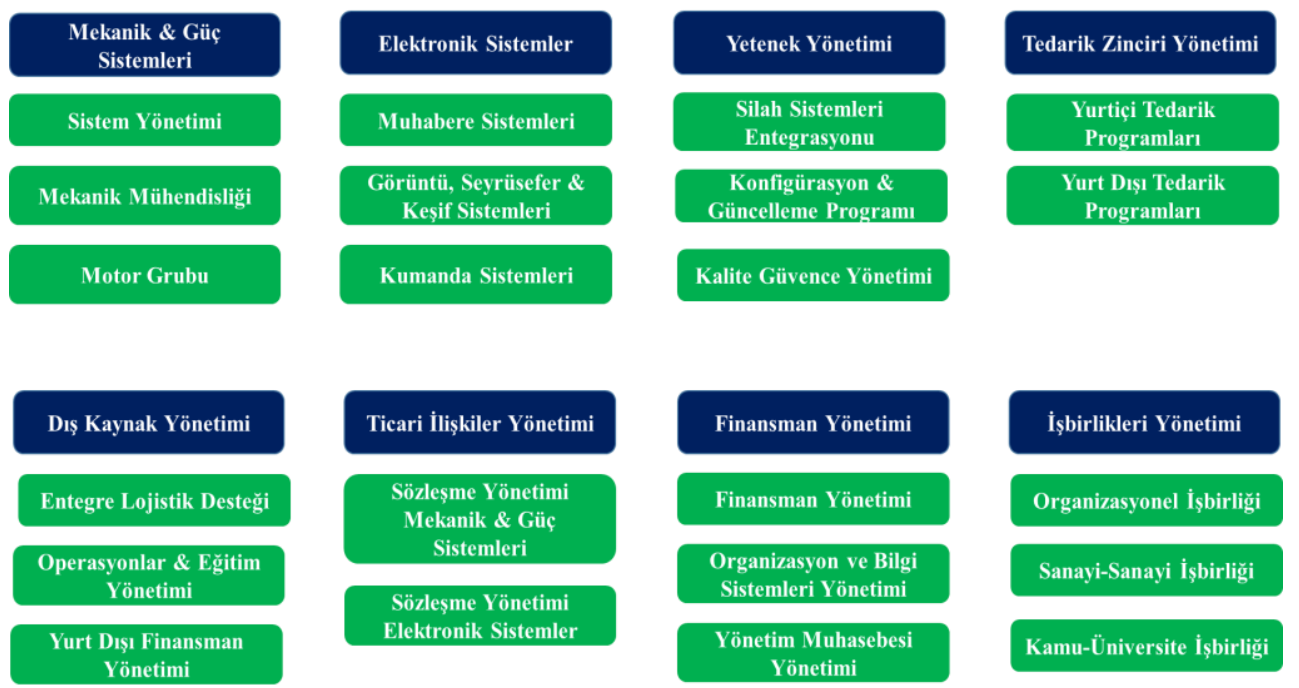

Şekil 8. Türkiye'de Savunma Tedarik Projeleri İçin Örnek EPE Şeması 
Şekil 8'de yer alan EPE yapısı, tüm platformlarda uygulanabilecek özellikte ve esneklikte tasarlanmıştır. Tedarik edilecek ana savunma sisteminin özelliğine göre bazı birimler kullanılmayabilir. Her durumda burada önerilen yapıda kamu, üniversite, sivil toplum kuruluşları ve özel sektör gibi farklı alanlardan katılımcılara yer verileceği gibi yabancı uzmanlıklardan veya bağımsız araştırmacılardan da faydalanılabilir.

$\mathrm{Bu}$ tip bir yapılanmayı desteklemek için bu çalışmada geliştirilen EPE oluşum aşamaları, EPE Çalışma Talimatı içeriği ve EPE Kontrol Listesi ise aşağıda sıralanmıştır. Burada önerilen EPE oluşum aşamaları mevcut tedarik sistemine uygun bir şekilde yapılandırılmıştır. EPE oluşum aşamaları Şekil 9'da gösterilmektedir.

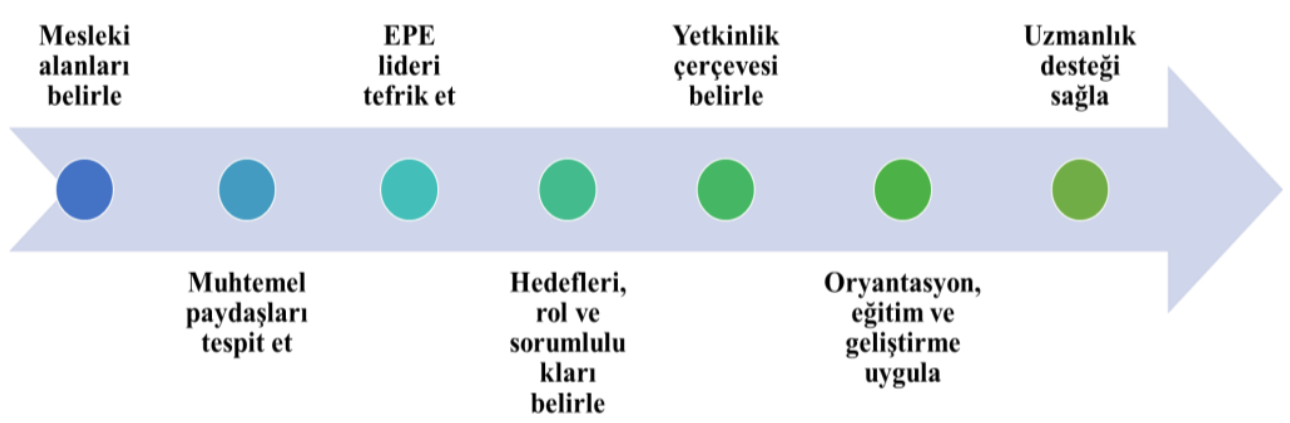

Şekil 9. EPE Oluşum Aşamaları

Savunma tedarik projelerinin ilk fazının başlangıcında oluşturulacak EPE'lerin oluşum aşamaları aşağıda da listelenmiştir.

- Proje aktivitelerinin gerçekleştirilebilmesi için ihtiyaç duyulacak mesleki alanların belirlenmesi

- Belirlenen bu alanlardan projede yer alması muhtemel paydaşların tespit edilmesi

- $\quad$ EPE liderinin tefrik edilmesi

- EPE'nin hedefleri, rol ve sorumluluklarının belirlenmesi

- $\quad$ EPE için yetkinlik çerçevesinin belirlenmesi 
Savunma Tedarik Proje Yönetiminde Entegre Proje Ekiplerinin Kullanımına Yönelik Bir Model Önerisi

- $\quad$ EPE üyelerinin oryantasyonu ve eğitilmesi

- $\quad$ EPE'ye tedarik makamı tarafından uzmanlık desteği sağlanması

EPE'lerin oluşturulması kadar çalışma koşullarının da projelerin özelinde düzenlemesi gerekmektedir. EPE'ler farklı çalışma kültürlerinden gelen üyeler tarafindan oluşturulacağ 1 için kişilere mümkün olduğu kadar açık, net ve anlaşılır bir şekilde görev verilmesi, projeler için kritik başarı göstergesidir. Bu çerçevede hazırlanacak EPE Çalışma Talimatı içeriğinde asgari aşağıdaki konularda bilgi yer alabilir.

- Projenin Özeti

- EPE Görevleri

- $\quad$ EPE Üyeleri, Rol ve Sorumlulukları

- $\quad$ EPE İletişim Yönetim Prosedürü

- İletişim Teknolojisi

- İletişim Yöntem ve Araçları

- İletişim Modeli

- Raporlama Usul ve Esasları

Savunma tedarik projeleri, teknoloji edinimi vizyonunda gerçekleştirilen projeler olduğu için hem örnek uygulamaları barındırmakta hem de iyi uygulama örnekleri yaratmaktadır. Bu alanda sağlanacak başarılar diğer sektör ve alanlarda da kullanım alanı bulacaktır. Savunma tedarik projelerinin yönetiminde Proje Yönetim Enstitüsü (Project Management Institute - PMI) tarafindan önerilen metodolojinin kullanımı benimsenmiş ve yaygınlaşmıştır. Bu çalışmada yapılan inceleme ve öneriler çerçevesinde, PMI proje yönetimi metodolojisine uygun şekilde aşağıdaki kontrol maddelerini içerecek şekilde bir Kontrol Listesi hazırlanabilir. Böylelikle EPE'lerin kullanımı proje yönetimine daha rahat ve kolay bir şekilde entegre edilebilir.

- EPE'nin misyonu, amacı ve hedef(ler)i açık ve net bir şekilde ifade edilmiş mi? 
- $\quad$ EPE'den beklenen işler tanımlanmış mı?

- Paydaşlar belirlenmiş mi? Paydaş beklentileri ve gereksinimleri netleştirilmiş mi?

- İş kırılım yapısı, faaliyetlerin tamamlanma zamanları ve teslimatlar belirlenmiş mi?

- EPE üyeleri fazlara uygun şekilde tanımlanmış mı?

- EPE için oryantasyon eğitimi ve hizmet içi eğitim planlanmış mı?

- $\quad$ EPE üyeleri için bireysel performans hedefleri belirlenmiş mi?

- EPE için sorumluluk tablosu oluşturulmuş mu?

- $\quad$ Proje performans göstergeleri tespit edilmiş mi?

- EPE iletişim ve koordinasyon usulleri belirlenmiş mi?

- Performans geri bildirimleri planlanmış mı?

- Ödüllendirme programı belirlenmiş mi?

- EPE çalışma talimatı hazırlanmış mı?

- EPE çalışma talimatı gözden geçirme ve güncelleme usulü belirlenmiş mi?

- EPE raporlama usul ve esasları belirlenmiş mi?

- Anahtar dış paydaşlarla etkileşim mekanizmaları tasarlanmış mı?

- EPE karar verme usul ve esasları belirlenmiş mi?

\section{Tartışma ve Sonuç}

Kendine has özellikleri ile diğer sektörlerden ayrılan savunma sanayi projelerindeki temel riskler arasında insan kaynakları uygulamalarından yeterince yararlanılmaması yer almaktadır. Bu nedenle, riskleri kontrol altına almak için uygulanacak yöntemlerden birisi, erken aşamadan itibaren tedarik zinciri içerisinde ileriye ve geriye doğru yer alan aktörlerle iş birliği stratejisidir. Tedarik makamının sanayi ile iş birliği yapması; yetenek geliştirmek, yatırım tekrarlarından kaçınmak 
Savunma Tedarik Proje Yönetiminde Entegre Proje Ekiplerinin Kullanımına Yönelik Bir Model Önerisi

ve kaynak israfını önlemek için de kullanılan bir araçtır. Bu doğrultuda 1990'ların ortasından itibaren simülasyon tabanlı tedarik, akıllı tedarik ve evrimsel tedarik stratejileri ile müşterek yetenekler entegrasyon ve geliştirme konsepti ve sistem yaklaşımı kapsamında EPE’lerin kullanıldığı görülmektedir. Böylelikle tedariki yapılacak savunma yeteneğinde tüm tarafların yetkinliğinden faydalanılmaktadır. Özellikle karmaşık, belirsiz, uzun süreli ve çok taraflı projelerde EPE'nin kullanımı giderek daha önemli hale gelmektedir.

Bununla birlikte savunma sektörü gibi teknolojideki hızlı değişim, tehdit algısı, kullanıcı ihtiyaçları, yüklenici pozisyonu, ekonomik vb. nedenlerden dolayı belirsizliğin yoğun olduğu ve mali, teknik ve takvim açısından risk yönetiminin ön planda tutulduğu bir sektörde EPE'lerin proje yönetiminde kullanılmasına yönelik çalışmalar yetersiz, hatta yok denecek kadar azdır. Alanyazındaki bu yetersizliğe vurgu yapmak ve gelişen savunma sektöründe EPE'lerin kullanılmasına katkıda bulunmak maksadıyla hazırlanan bu çalışmanın amacı, Türkiye'de EPE'lerin kullanımına yönelik bir model önerisi sunmak olarak belirlenmiştir. Özellikle özgün teknolojik savunma sistemine sahip olmak isteyen Türkiye açısından ekosistemdeki tüm aktörlerin teknoloji ve bilgisinin sinerji yaratacak şekilde bir araya getirilmesi çalışmanın önemini artırmaktadır. Bu doğrultuda öncelikle proje yönetimi, savunma tedarik stratejileri ve EPE'lerin kullanımı incelenmiştir.

Savunma tedarik strateji ve yaklaşımları bağlamında EPE'lerin kullanılmasına ilişkin yapılan tespit ve değerlendirmeler sonucunda tedarik makamı açısından ana savunma sistemlerinin tedarik projelerinde EPE'lerin kullanımını sağlayabilmek için bir model önerisi yapılmıştır.

Türkiye açısından savunma tedarik projelerinde EPE'lere yer verilmesinin faydalı olacağı düşünülmektedir. Ancak akla gelen bazı soruların da cevaplanması önemlidir. Gelişen sanayiyle birlikte paydaşların artması sonucunda EPE'lerin oluşumunda denge ne kadar gözetilebilir? Özellikle kamu alımlarını düzenleyen regülasyonlar göz önünde bulundurulduğunda haksız rekabet koşullarının yaratılmasının önüne nasıl geçilebilir? EPE’lerde görevlendirilecek asker ve sivil çalışanların rotasyon durumları ne şekilde yönetilebilir? Teknoloji kazanımı hedefinde kritik olan know-how oluşumu nasıl sağlanabilir ve nasıl muhafaza edilebilir? 
Süreçlerin oluşturulmasında tamamlanan projelerden elde edilen tecrübeler esas alınmakla birlikte risk odaklı bir yaklaşımla karşıllaşılabilecek muhtemel durumlar da düşünülerek esnek tasarımlar yapılmalıdır. Buradan hareketle muhtemel riskler içerisinde nitelikli işgücü, kamu-üniversite-sanayi iş birliği, regülasyona uyum konuları ön plana çıkmaktadır. Bu çerçevede Türkiye açısından EPE'ler kullanımına yönelik değerlendirilmesi bağlamında savunma tedarikinde kullanılabilecek bir EPE yapısı önerilmiştir. Burada önerilen EPE yapısı tüm platformlarda uygulanabilecek özellikte ve esneklikte tasarlanmıştır. Tedarik edilecek ana savunma sisteminin özelliğine göre bazı birimler kullanılmayabilir. Her durumda burada önerilen yapıda kamu, üniversite, özel ve sivil toplum gibi farklı sektörden katılımcılara yer verileceği gibi yabancı uzmanlıklardan veya bağımsız araştırmacılardan da faydalanılabilir.

Önerilen yapının kullanılabilir hale getirilebilmesi için kritik başarı faktörleri; risk odaklılık, değer yaratacak sürdürülebilir uygulamalar, net tanımlanmış süreçler ve görev tanımlanı, sürekli iyileştirme sağlayan performans yönetimi, şeffaf ve hesap verilir bir muhasebe bilgi sistemi, iyi uygulamaların paylaşımı ve yenilikçiliğin teşvik edilmesi olarak sıralanabilir. Bu nedenle çalışmada savunma tedarik projelerinin ilk fazının başlangıcında oluşturulacak EPE'lerin oluşum aşamalarına yer verilmiştir. Ayrıca, EPE'lerin oluşturulması kadar çalışma koşullarının projelerin özelinde düzenlemesi bir esasa bağlanmalıdır. EPE'ler farklı çalışma kültürlerinden gelen üyeler tarafindan oluşturulacağı için mümkün olduğu kadar açık, net ve anlaşılır bir şekilde görev verilmesi projeler için kritik başarı göstergesidir. Bu doğrultuda EPE'lerin çalışma usul ve esasları ile uygulamada standardizasyonun sağlanması için bir kontrol listesi de hazırlanmıştır.

Proje tedarik yönetiminin amacı maliyetleri minimize etmekten değerin artırılmasına doğru değişmiştir. Türkiye'de millî ana yüklenicilik sistemi benimsendiği için önceliği ana yüklenicilerin alması kaçınılmaz olmakla birlikte özgün teknolojilere sahip olabilmek için alt yüklenicilere de uygun şekilde yer verilmesi önem arz etmektedir. Nitekim tedarik zinciri içerisinde yer alan alt yükleniciler ürünün \%60-70'ini karşıladığı halde EPE yapısında yer alamamaktadır. $\mathrm{Bu}$ nedenle ana yüklenicilik sisteminde EPE'lerin kullanımının irdelenmesi bir zorunluluk haline gelmiştir. Ancak genel olarak savunma yönetimi alanında özel olarak savunma tedarik yönetimi kapsamında çalışmaların yok denecek kadar az 
Savunma Tedarik Proje Yönetiminde Entegre Proje Ekiplerinin Kullanımına Yönelik Bir Model Önerisi

olması Türkiye için bir model geliştirilmesi için akademik altyapının oluşturulmasını yeterince destekleyememektedir. Savunma tedarik projelerinin yönetimi açısından ulusal kültürümüz bağlamında yenilikçi modeller ortaya konması kamunun gelişimi kadar savunma sanayinin gelişimi için de önemlidir. Benzer şekilde savunma tedarik projelerinin yönetimi; her iki sektöre beşerî sermaye yetiştiren üniversiteler için de bir gelişim ekseni olarak durmaktadır. Bu çerçevede nitelikli işgücü yetiştirilmesi için müfredat önerileri, politika yapıcılar için politika önerileri, tedarik makamları için yöntem önerileri, savunma sanayi için strateji önerileri yapılması kritik öneme haizdir. Bu nedenle, öncelikle EPE'lere ilişkin bir yetkinlik çerçevesi çizilmesinde fayda olabilir. EPE üyelerinin özellikleri arasında; temsil, bilgi, beceri, açık fikirlilik, ekip çalışması becerisi, bağlılık ve zamana riayet yer almalıdır (MITRE, 2008). Ayrıca, başarılı bir EPE'de görev tanımlarının net bir şekilde yapılmış olması, mesleki bağlılık ile birlikte projeye inanç olması, proje hedeflerinin anlaşı1ır olması, gelecek odaklı sistem bütünlüğü içerisinde yaklaşılması, kendini yöneten öğrenen ekipler olması, paydaşlarla iletişime ve iş birliğine açık olması, hesap verebilir ve sorumluluk sahibi olması önemlidir.

$\mathrm{Bu}$ alanda çalışacak akademisyen, araştırmacı ve uzmanlara EPE'lerin kullanımını kolaylaştıracak yapıların üzerinde çalışma yapmaları ve iyi uygulama örnekleri üzerinden vaka analizleri çalışmaları önerilebilir. Diğer taraftan kamunun tamamlanmış, devam eden ve tasarlanan projelere ilişkin veri paylaşımını artırması alanda çalışma yapacak akademisyenler, araştırmacılar ve uzmanlar için çarpan etkisi yaratabilir ve çalışmaların yabancı menşeli projeler üzerinden yapılması yerine ulusal kültürümüzün bağlamında daha özgün çalışmalar yürütülebilmesini sağlayabilir.

\section{Extended Summary}

\section{Introduction}

One of the primary risks in the acquisition projects is to complete it within performance criteria in compliance with time and cost target. Employing integrated project teams (IPT) may be a tool to mitigate mentioned risks in acquisition of longterm complex systems in particularly defense, aviation, and space sector. However, there is a scant literature on employment of IPTs in defense sector whereby uncertainties due to user requirements, supplier position, economy and technology are confronted and risk management regarding finance, technic, and schedule are 
attached great significance. This study, which is prepared to highlight the need and contribute to the use of IPTs in developing defense sector, aims to propose a model regarding employing them in Turkey. Gathering know-how and technology of the actors in ecosystem to create synergy on behalf of Turkey, aiming to have indigenous defense technology, promotes the significance of the study. To this end, this study proposes an organizational chart, team formation phases, operational procedures, and a check list to be employed in defense acquisition projects in Turkey.

\section{Conceptual Framework}

Project management is the gathering of similar activities in a specific time period with a specific budget to meet a specific need in general. Essentially project management is the application of knowledge, processes, skills, tools and techniques to project activities in order to fulfill the requirements of the project. The project's successful output is only possible with the gathering of compatible individuals. The project team is a group that consists of experts in related subjects coming together for a specific purpose in order to carry out the project from the beginning to the end. Integrated teamwork and comprehensive cooperation is highly recommended to achieve the optimal output. Thus, the interests, needs, expectations, constraints and risks of all stakeholders can be taken into account. Concurrent engineering, integrated project teams (IPT) and multi-functional teams as well as integrated product development teams are such teamwork employed in the projects. IPTs further the efforts in similar structures. They carry out its design and execution activities, and even administrative activities with the participation of all stakeholders.

\section{Model Proposal for Turkey}

As a result of the review of the use of IPTs, a model proposal was made for the acquisition authority to ensure the employment of IPTs in the main defense systems acquisitions. The IPT structure proposed here is designed to be flexible and applicable to all platforms. Some units may not be used depending on the characteristics of the main defense system. In any case, the structure proposed here will include participants from different sectors such as public, university, private and civil society, as well as foreign experts or independent researchers. 
Savunma Tedarik Proje Yönetiminde Entegre Proje Ekiplerinin Kullanımına Yönelik Bir Model Önerisi

Critical success factors of IPT structure are risk orientation, sustainable practices that will create value, clearly defined processes and job descriptions, performance management leading to continuous improvement, a transparent accounting system, sharing good practices and promoting innovation. Competency framework for IPTs may include, but not limited to, representation, knowledge, skills, open-mindedness, teamwork skills, commitment and time management. In addition, professional commitment, understanding of the project objectives, approaching future-oriented system integrity, self-directed learning teams, openness to communication and cooperation with stakeholders, accountability and responsibility are important for a successful IPT formation.

\section{Results and Recommendations}

Main priority of Turkish national acquisition system is employment of the prime contractor. However, the subcontractors cannot be included in the IPT structure although they cover $60-70 \%$ of the supply chain. For this reason, it may be beneficial to review the structure of IPTs and to propose a comprehensive approach. Therefore, in the study, the formation stages of IPTs are included at the beginning of the first phase of defense projects. In addition, the arrangement of the working conditions specific to the projects should be based on the establishment of IPTs. In this direction, a checklist has been prepared to ensure standardization in practice with the working procedures and principles of IPTs. Nonetheless, there is a scant literature on IPTs and few practices regarding good teamwork.

It is, therefore, highly recommended that academicians, researchers and experts work on structures that will facilitate the use of IPTs and discuss case studies based on good practices. On the other hand, increasing knowledge sharing on completed, ongoing and designed projects by the public can create a multiplier effect for academics, researchers and experts who will work in the field, and it can enable more original studies to be carried out in the context of our national culture, rather than through foreign projects.

\section{Kaynakça}

\section{Kitaplar}

Hayes, R.H., Wheelwright, S.C. and Clark, K.B. (1988). Dynamic Manufacturing. The Free Press Division, Macmillan Inc, Collier Macmillan Pub. 
İngiltere Savunma Bakanlığı (2005). Defence Industrial Strategy: Defence White Paper. London: HMSO .

İstanbul Sanayi Odası (2009). Proje Yönetimi Kılavuzu. İSO Yayın No: 2009/24, İstanbul.

Mawdsley, J. (2015). France, the UK and the EDA. In: N. Karampekios and I. Oiknomou, eds. The European Defence Agency. Arming Europe. London: Routledge, 139-154.

PMI (2013). Proje Yönetimi Bilgi Birikimi Kllavuzu (PMBOK® Kllavuzu) Altıncı Baskı. İstanbul: PMI TR.

\section{Makaleler}

Bahill, A.T. and Gissing, B. (1998). Re-Evaluating Systems Engineering Concepts Using Systems Thinking. IEEE Transaction on Systems, Man and Cybernetics, Part C: Applications and Reviews. 28(4), 516-527.

Bochenek, G.M. and Ragusa, J.M. (2004). Improving Integrated Project Team Interaction through Virtual Collaboration. Engineering Management Journal, 16(2), 3-12.

Boehm, B. and Hansen, W.J. (2001). The Spiral Model as a Tool for Evolutionary Acquisition. Journal of Defense Software Engineering, 14(5), 4-11.

Buchanan, D. A. (1991). Vulnerability and Agenda: Context and Process in Program Management. British Journal of Management, 2, 121-132.

Calcara, A. (2017). State-defence industry relations in the European context: French and UK interactions with the European Defence Agency. European Security, 26(4), 527-551.

Carman, K.R. (2009). Building Championship Teams. Contract Management, 49(10), 42-51.

Cohee, G. L., Barrows, J. and Handfield, R. (2019). Early supplier integration in the US defense industry. Journal of Defense Analytics and Logistics, 3 (1), 228.

Cook, N. (1998). Smart Moves. Jane's Defence Weekly, 9 September, 36-38. 
Savunma Tedarik Proje Yönetiminde Entegre Proje Ekiplerinin Kullanımına Yönelik Bir Model Önerisi

Dwivedi, S. N. and Kumbakonam, A. (2002). Effective Team Building Process and Team Leadership for Integrated Product and Process Development. International Journal of Human Resource Development and Management, 2(3/4), 415-435.

Erridge, A. and Nondi, R. (1994). Public Procurement, Competition and Partnership, European Journal of Purchasing and Supply Management, 1(3), 169-79.

Erridge, A. and Greer, J. (2000). Policy Network Analysis of UK Central Government Civil Procurement. Public Policy and Administration, 15(4), 25-49.

Fleming, Q. W. and Koppelman, J. M. (1996). Integrated project development teams: another fad... or a permanent change. International Journal of Project Management, 14(3), 163-168.

Ford, R. and McLoughlin, F. (1992). Successful Project Teams: A study of MIS Managers. IEEE Transactions on Engineering Management, 39(4), 312317.

Gadeken, O.C. (2005). PM Leadership: Seven Keys to Success. Defense AT\&L, January-February, 10-12.

Galloway, I. (1998). Private finance comes of age. Defence Procurement Analysis, Autumn, 17-19.

Gove, R. and Uzdzinski, J. (2013). A performance-based system maturity assessment framework. Procedia Computer Science, 16, 688-697.

Guo, Q., Li, T. and Yang, X. (2008). Research on requirements generation process of army weapon equipment, Journal of Academy of Armored Force Engineering, 2, 10-13.

Hitt, M.A., Hoskisson, R.E. and Nixon, R.D. (1993). A Mid-Range Theory of Interfunctional Integration, Its Antecedents and Outcomes. Journal of Engineering and Technology Management, 10, 161-185

Koufteros, X., Vonderembse, M. and Doll, W. (2001). Concurrent engineering and its consequences. Journal of operations management, 19(1), 97-115. 
Liu, W.W., Liu, F.S., Xu, D. and Zhang, Q. (2012). Analysis of joint capabilities integration and development system of US ARMY. IEEE: International Conference on Quality, Reliability, Risk, Maintenance, and Safety Engineering, 1349-1353.

Moore, D.M. and Antill, P.D. (2001). Integrated Project Teams: the way forward for UK defence procurement. European Journal of Purchasing \& Supply Management, 7(3), 179-185.

Mortlock, R.F. (2020). Studying Acquisition Strategy Formulation of Incremental Development Approaches. Defense Acquisition Research Journal, 27(3), 264-311.

Müslüm, S., Topcu, M.K. ve Mala, M. (2010). Savunma Tedarikinde Güncel Yaklaşımlar: Evrimsel Tedarik Stratejisi ve Türkiye Açısından Bir Değerlendirme. Savunma Bilimleri Dergisi, 9(2), 91-115.

Pane Haden, S.S., Humphreys, J.H., Cooke, J. and Penland, P. (2012). Applying Taylor's Principles to Teams: Renewing a Century-Old Theory. Journal of Leadership, Accountability and Ethics, 9(4), 11-20.

Pinheiro, B. A. (2010). How Do Managers Control Technology-Intensive Work? Journal of Technology Management\&Innovation, 5(2), 1-12.

Rahman, M.M. and Kumaraswamy, M.M. (2008). Relational Contracting and Teambuildings: Assessing Potential Contractual and Non-Contractual Incentives. Journal of Management in Engineering, January, 48-63.

Sanderson, J. (2009). Buyer-supplier partnering in UK defence procurement: looking beyond the policy rhetoric. Public Administration, 87(2), 327-350.

Söderlund, J. and Bredin, K. (2006). HRM in Project-Intensive Firms: Changes and Challenges. Human Resource Management, 45(2), 249-265.

Topcu, M.K., Mala, M. and Müslüm, S. (2015). A Study on Defense Acquisition Models with an Emerging Market Perspective. The Case of Turkey. Journal of Defense Resources Management, 6(2), 95-102.

Turk, W. (2006a). The Five P's in Project Management. Defense AT\&L, JulyAugust, 22-25. 
Savunma Tedarik Proje Yönetiminde Entegre Proje Ekiplerinin Kullanımına Yönelik Bir Model Önerisi

Turk, W. (2006b). Seven Deadly Sins of Project Management. Defense AT\&L: January-February, 24-27.

Turk, W. (2007), 21st Century Project Management Competencies. Defense AT\&L, January-Februray, 22-25.

Valdez, R. ve Kleiner, B.H. (1996). How to Build Teamwork in the Defence Industry. Team Performance Management, 2(2), 41-48.

Winn, M. T. (2006). Reduce Program Confusion Through an Integrated Product/Program Team. Contract Management, 46(10), 36-41.

Zakarian, A. and Kusiak, A. (1999). Forming teams: an analytical approach. IIE Transactions, 31(1), 85-97.

Zittel, R. (2001). The Reality of Simulation-based Acquisition and an Example of U.S. Military Implementation. Acquisition Review Quarterly, Summer, 121132.

\section{Tezler}

Ellman, J. E. (2009). The Role of Evolutionary Acquisition and Spiral Development in the Failure of the Army's Future Combat System. Yüksek Lisans Tezi, Georgetown University, Washington, D.C.

\section{Kongre ve Sempozyum}

Bochenek, G. M. and Ragusa, J. M. (2003). Virtual (3D) collaborative environments: An improved environment for integrated product team interaction? Proceedings of the 36th Annual Hawaii International Conference on System Sciences, IEEE, Hawaii, ABD.

Cook, S.C., Nowakowski, S. and Unewisse, M. (2013). Towards an SoS Engineering Approach for Integrating Australian Defence Force Capabilities. Proceedings of Systems Engineering Test and Evaluation Conference, Systems Engineering Society of Australia.

Gross, D.C., Tucker, W.V. and Cameron, S.E. (2007). Whatever happened to Simulation Based Acquisition? Simulation Tecchnology Conference. 
Korkmazyürek, H. (2004). Savunma Tedarikinde Reform Stratejisi: Proje Yönetimi Açısından Bir Bakış. 12 'nci Ulusal Yönetim-Organizasyon Kongresi, 27-29 May1s 2004, Bursa, 212-218.

Ullah, I., Tang, D. and Yin, L. (2015). Engineering Change Implications on Product Design: A Review of the Literature. International Conference on Education, Management and Computing Technology (ICEMCT-15), Atlantis Press, Tianjin, 1679-1691.

\section{Web Siteleri}

Hollier, W. and Beckett, P. (2002). Simulation-Based Acquisition: Architecture and Implementation - Part 1. SimTecT 2002. 02.01.2020 tarihinde http://www.siaa.asn.au/get/2395361789.pdf adresinden alınmıştır.

Fox, J.R. (2011). Defense acquisition reform, 1960-2009: An elusive goal. Center of Military History. 12.11.2019 tarihinde https://history.army.mil/html/books/051/51-3-1/index.html adresinden alınmıştır.

\section{Kılavuzlar}

ABD Enerji Bakanlığı (2012). Integrated Project Team: Guide for Formation and Implementation, DOE G 413.3-18A. ABD: Washington DC.

ABD Hava Kuvvetleri Malzeme Komutanlığı (1993). Guide on Integrated Product Development, Air Force Material Command. ABD.

ABD Savunma Bakanlığı (1996). Guide to Integrated Product and Process Development, Version 1.0, ABD: Washington, DC.

ABD Savunma Bakanlığı (2007). Instruction 5000.2: Operation of the Defense Acquisition System. ABD: Washington, DC.

Hughes Aircraft Company (1994). Integrated Product Development, Hughes Guide to Using Integrated Product Teams, Hughes Surface Systems.

MITRE (2008). Integrated Project Team (IPT) Start-up Guide. Tracking Number: 08-1645. ABD: Massachusetts. 
Savunma Tedarik Proje Yönetiminde Entegre Proje Ekiplerinin Kullanımına Yönelik

Bir Model Önerisi

NASA (2017), NASA Systems Engineering Handbook, SP-2016-6105 Rev2., 12th Media Services, https://www.nasa.gov/sites/default/files/atoms/files/nasa_ systems_engineering_handbook_0.pdf.

Office of the Under Secretary of Defense for Acquisition, Technology \& Logistics. (2007). The Defense Acquisition System (DoDD 5000.01). http://www.acqnotes.com/Attachments/DoD\%20Directive\%205000.01.pdf

\section{Raporlar}

Aldridge, E.C., Jr. (2002). Evolutionary Acquisition and Spiral Development, Memorandum, Office of the Under Secretary of Defense for Acquisition, Technology, and Logistics (USD[AT\&L]), Washington, D.C.

Coble, M., Royster, J., Glandon, G., Stewart, J., Pham, P., Taylor, B., Bailey, D. and Herndon, K. (2014). Improving the Prototyping Process in Department of Defense Acquisition. Systems Engineerıng Capstone Project Report, Monterey, California.

Darnis, J. P., Gasparini, G., Grams, C., Keohane, D., Liberti, F., Maulny, J. P. and Stumbaum, M. B. (2007). Lessons learned from European defence equipment programmes. Occasional Paper: 69. Paris: EU Institute for Security Studies.

Grasso, V. B. (2010). Defense Acquisition: Use of Lead System Integrators (LSIs)Background, Oversight Issues, and Options for Congress. Congressional Research Service, 7-5700. Washington, D.C.

İngiltere Sayıştay (2005). Ministry of Defence: Major Projects Report. London: HMSO.

Kirkpartick, D. (2003). A UK Perspective on Defence Equipment Acquisition. Institution of Defence and Strategic Studies, Working Paper, No: 41, Singapore.

McKinsey and Company (1998). Transforming the UK's Defence Procurement System. Final Report, 20 February.

Menker, L. J. (1990). Results of the aeronautical systems division critical process team on integrated product development (No.ASD-TR-90-5014). 
Aeronautical Systems Dvision Air Force Systems Command, WrightPatterson AFB, Ohio, ABD.

Office of Government Commerce (OGC) (2007). The Integrated Project Team:

Teamworking and Partnering-Achieving Excellence in Construction Procurement Guide, OGC Yayınları. 